\title{
Foreclosing on Opportunity: State Laws and Mortgage Credit
}

\author{
Karen M. Pence \\ Board of Governors of the Federal Reserve System \\ Karen.Pence@FRB.GOV
}

(202) 452-2342

May 13, 2003

\begin{abstract}
Foreclosure laws govern the rights of borrowers and lenders when borrowers default on mortgages. Many states protect borrowers by imposing restrictions on the foreclosure process; these restrictions, in turn, impose large costs on lenders. Lenders may respond to these higher costs by reducing loan supply; borrowers may respond to the protections imbedded in these laws by demanding larger mortgages.

I examine empirically the effect of the laws on equilibrium loan size. I exploit the rich geographic information available in the 1994 and 1995 Home Mortgage Disclosure Act data to compare mortgage applications for properties located in census tracts that border each other, yet are located in different states. Using semiparametric estimation methods, I find that defaulter-friendly foreclosure laws are correlated with a four percent to six percent decrease in loan size. This result suggests that defaulter-friendly foreclosure laws impose costs on borrowers at the time of loan origination.
\end{abstract}

I am grateful to John Karl Scholz, Yuichi Kitamura, and Bob Haveman for their guidance with this project and to David Brown, Mary DiCarlantonio, Greg Grothe, Michele Rambo, Keiko Snell, and James Tedrick for outstanding research assistance. For helpful comments, I thank the faculty and students of the University of Wisconsin, my Federal Reserve Board colleagues, Chuck Capone, and seminar participants at the Universities of Maryland, California-Berkeley, Texas-Austin, Texas A\&M, Western Ontario, and North Carolina-Greensboro, as well as the participants from Wharton, Freddie Mac, the San Francisco Fed, the Treasury Department, and the Congressional Budget Office. I received generous financial support from a U.S. Department of Housing and Urban Development doctoral dissertation grant, the Christensen Award in Empirical Economics, and the Social Science Research Council Program in Applied Economics, funded by the MacArthur Foundation. This research does not necessarily reflect the views of the Board of Governors of the Federal Reserve System, its members, or its staff; the U.S. Department of Housing and Urban Development; the Social Science Research Council; or the MacArthur Foundation. 


\section{Introduction}

When a borrower defaults on a home mortgage, the lender may attempt to recover its losses by repossessing and selling the property. However, estimated losses on these foreclosures range from 30 percent to 60 percent of the outstanding loan balances because of legal fees, foregone interest, and property expenses. ${ }^{1}$ State foreclosure laws also affect these losses: foreclosures in some states are quick, low-cost procedures that provide scant protections for borrowers, while laws in other states confer substantial benefits on borrowers and correspondingly large costs on lenders. Laws in these "borrower-friendly" states are intended to protect homeowners in distress. However, if lenders pass the higher associated costs onto borrowers, the laws may have the unintended consequence of reducing the supply of mortgage credit.

In this paper, I use semiparametric methods to examine the effect of foreclosure laws on the size of approved mortgage loans. This effect is, a priori, ambiguous. As mentioned above, lenders may respond to the higher expenses associated with costly foreclosure laws by charging higher interest rates, requiring larger downpayments, or both. Jones (1993), for example, documents that lenders in Alberta, Canada, increased downpayment requirements after suffering large default rates linked to foreclosure laws. However, defaulter-friendly foreclosure laws provide borrowers with wealth insurance against falling house prices. If risk-averse borrowers value this insurance more than its cost, mortgage demand may increase.

It is difficult to identify the effects of foreclosure laws on the mortgage market because both laws and real estate markets exhibit strong regional patterns. One type of property law governing foreclosures is prevalent on the East Coast, another in the Midwest, and yet another on the West Coast. Real estate markets also vary strikingly across the United States. In 1990, for example, real house prices increased 17 percent in Seattle, Washington, and 15 percent in Aurora, Illinois, while they decreased 11

\footnotetext{
${ }^{1}$ See Capone (1996). Clauretie and Herzog (1990) and Ciochetti (1997) also find loss rates in this range; the National Home Equity Mortgage Association estimates foreclosure losses at 50 cents on the dollar.
} 
percent in New Haven, Connecticut, and Charleston, West Virginia. ${ }^{2}$ In a simple crosssectional regression, a regional shock to the housing market could be misinterpreted as an effect of the foreclosure laws.

I control for this identification problem by comparing approved home mortgage applications in census tracts that are geographically near each other but are located in different states. The proximity of the houses suggests that they may take on similar values for unobserved characteristics that might otherwise bias the estimation. However, different foreclosure laws govern the mortgages. Studies such as Holmes (1998) and Black (1999) have used a similar "borders" identification strategy to estimate the effect of state right-to-work laws on the location of manufacturing and the effect of school quality on house prices, respectively. I carry out this strategy using the millions of geocoded loan applications collected in 1994 and 1995 under the Home Mortgage Disclosure Act.

To capture local variation in real estate markets in as flexible a manner as possible, I implement a semiparametric estimator that allows unobserved characteristics to take on a different value at each census tract. As long as these characteristics change smoothly over space, while the laws change discontinuously at the state border, the effect of the laws is identified. Although a census-tract fixed effects model also allows unobserved characteristics to vary by census tract, it fails in this application because the census tracts fixed effects are collinear with the state laws. This semiparametric estimation strategy fits within the regression discontinuity framework discussed by Hahn, Todd, and Van der Klaauw (2001) and Porter (2002).

After controlling for these geographically varying factors, I find that loan sizes are four to six percent smaller in states with defaulter-friendly foreclosure laws. This finding is robust to several changes in specification. In contrast, a specification that ignores these regional factors indicates that foreclosure laws do not affect loan size, suggesting that studies that omit these factors may yield misleading results.

\footnotetext{
${ }^{2}$ See Poterba (1991).
} 
The decrease in loan size suggests that lenders respond to costly foreclosure laws by reducing loan supply. Smaller loan sizes may also reflect, in part, an effect of the laws on house prices: buyers may not be willing to pay as much for a house if they have difficulty obtaining financing. Although I control for house prices with the semiparametric estimation technique and with census tract housing characteristics, it is possible that the coefficient captures the effect of the laws on both loan size and on house prices. ${ }^{3}$

These findings suggest that policymakers face a tradeoff. They can facilitate the availability of low-priced mortgage credit, or they can provide protections to homeowners who experience financial difficulties, but they cannot do both. While several recent papers have explored a similar tradeoff engendered by bankruptcy law, ${ }^{4}$ very few have considered the role of foreclosure law, despite the primary role that housing plays in most household portfolios. This research begins to fill that gap.

\section{Costs and Benefits of Foreclosure Laws}

Previous papers have focused on three areas of property law that affect foreclosures: judicial foreclosure processes, statutory rights of redemption, and deficiency judgments. In this paper, I examine the effects of all three, although I argue below that a link between juducial foreclosure processes and lender costs is most plausible.

1. Twenty-one states, as shown in figure 1, require a judicial foreclosure process in which the lender must proceed through the courts to foreclose on a property. These states are concentrated in the northeastern and midwestern regions of the United States, although Florida, South Carolina, Louisiana, and New Mexico, among other states, also require the procedure. In all other states, lenders have the option of using a simpler, quicker, and cheaper nonjudicial procedure called

\footnotetext{
${ }^{3}$ HMDA does not include the value of the property underlying the loan or other loan terms such as the interest rate.

${ }^{4}$ See, for example, Gropp, Scholz, and White (1997).
} 
power of sale, in which a trustee oversees the sale of the property,

2. After the completion of the foreclosure sale, the homeowner can still regain the property in the nine states that permit a statutory right of redemption. Up to a year after the sale, depending on the state, homeowners can redeem their property for the foreclosure sale price plus foreclosure expenses. In some states, the homeowner retains ownership during this period. ${ }^{5}$ Statutory rights of redemption are prevalent in farming states, where crops may fail one year and succeed the next. As shown in figure 2, most statutory right-of-redemption states are located in the Great Plains region. State legislatures installed the provision in response to borrower demands for more protection during 19th-century depressions. ${ }^{6}$

3. Most states allow creditors to collect a deficiency judgment equal to the lender's foreclosure losses against the borrower's other assets. Although deficiency judgments are not often pursued, the threat of a deficiency judgment can be used to obtain concessions from the borrower. As shown in figure 3, nine states located in the western half of the United States forbid deficiency judgments for the typical home mortgage default case. ${ }^{7}$ These prohibitions were a response to perceived lending abuses during the Great Depression, when lenders would purchase foreclosed properties at prices far below the loan balance and then obtain a deficiency judgment against the borrower's other assets. ${ }^{8}$

Foreclosure laws can affect costs by imposing transaction costs; by prolonging the length of time in which lenders forgo interest on the loan and incur carrying costs

\footnotetext{
${ }^{5}$ As discussed in the data appendix in table 1 , some states allow a statutory right of redemption if the lender follows a judicial foreclosure process but not otherwise. I code a state as allowing a statutory right of redemption if it is available under the procedure a lender generally follows.

${ }^{6}$ See Capone (1996), p.126. The principle underlying the statutory right of redemption is even more ancient, dating back to ancient Hebrew Law. See Lev. 25:25-31.

${ }^{7}$ No state forbids deficiency judgments in all cases. California, like most states that restrict deficiency judgments, prohibits them only for owner-occupied, one- to four- family homes. As with the statutory right of redemption, I code a state as forbidding a deficiency judgment if it is unavailable under the foreclosure process a lender generally follows.

${ }^{8}$ See Capone (1996), p. 134.
} 
such as taxes and maintenance; and by shifting the relative bargaining power of the lender and borrower. Even when lenders pursue alternatives to foreclosure, foreclosure laws may affect the outcome. Lenders may be more willing to grant concessions to defaulters in states with costly laws because pursuing a foreclosure is so expensive.

The length of the foreclosure process appears to be an especially key factor. Illustrative calculations by Capone (1996), for example, suggest that delaying the foreclosure process on a $\$ 100,000$ loan by sixteen months increased costs by over $\$ 13,500$ in 1996. ${ }^{9}$ Another indicator of the value of a lengthy foreclosure process is the presence of "equity skimmers," who buy properties from defaulting borrowers and then rent out the property while manipulating the legal system to extend the process as much as possible. $^{10}$

Judicial procedures are substantially more time consuming than power-of-sale procedures. Wood (1997) finds that judicial foreclosures, on average, take 148 days longer than nonjudicial foreclosures, while Freddie Mac's guidelines for mortgage servicers indicate that foreclosures in the most time-consuming state, Maine (a judicial foreclosure state), take almost 300 days longer than in the quickest state, Texas (a power-ofsale state). ${ }^{11}$ Judicial processes also impose more transaction costs and are thought to introduce more uncertainty into the foreclosure proceedings than power-of-sale processes. From the borrower's perspective, the delays associated with a judicial foreclosure provide a lengthy period of free rent. In addition, judicial foreclosure processes provide safeguards against lender excesses. ${ }^{12}$

The link between a judicial foreclosure process and lender costs has been noted in both the popular press (Fleishman (2002)) and in more formal studies. As far back as the Great Depression, judicial foreclosures cost the Home Owners' Loan Corporation

\footnotetext{
${ }^{9}$ See p. 43.

${ }^{10}$ See Polk (1988).

${ }^{11}$ Estimates taken from Jankowski (1999), p. 2-11. These estimates assume no complications in the foreclosure process; filing for bankruptcy, for example, can add an additional six months.

${ }^{12}$ In 2000, in response to complaints about predatory lending in the District of Columbia, housing activists pressed for changes in city law that would allow borrowers to contest predatory foreclosures in court.
} 
twice as much as power-of-sale foreclosures. ${ }^{13}$ More recently, Touche, Ross and Co. (1975), Clauretie (1989), Clauretie and Herzog (1990), Ciochetti (1997), and Wood (1997) have also documented a relationship between judicial foreclosures and lender costs.

Statutory rights of redemption and deficiency judgments also affect lenders' costs. Statutory rights of redemption prolong the foreclosure process and may depress prices at the foreclosure sale, since the new owner cannot obtain a clear title for the property. Deficiency judgments affect relative bargaining power: the threat of a deficiency judgment can be used to extract concessions from borrowers.

However, in practice borrowers rarely exercise statutory rights of redemption and lenders rarely pursue deficiency judgments. Borrowers generally default when the size of the loan exceeds the value of the property; since this condition is usually still true a year after the foreclosure sale, they have no incentive to redeem the property. Deficiency judgments are rarely profitable because most borrowers in foreclosure have very few resources. Capone (1996) notes that deficiency judgments are "rarely used in practice" and are generally pursued only against "investors, repeat defaulters, and nonhardship cases." ${ }^{14}$ By contrast, judicial foreclosures affect every foreclosure in a state that requires the process.

Researchers have not been able to document a consistent link between these laws and lender costs. Clauretie (1989) and Clauretie and Herzog (1990) find lower loss rates in states that prohibit statutory rights of redemption. When Clauretie and Herzog (1990) exclude California from the specification, they find higher loss rates in states that prohibit deficiency judgments, but when they include California they find lower loss rates. ${ }^{15}$ Jones (1993) and Ambrose, Capone, and Deng (2001) find higher default rates in areas that prohibit deficiency judgments. However, Wood (1997) finds that

\footnotetext{
${ }^{13}$ Author's calculation from Bridewell (1938), p. 555.

${ }^{14}$ See p. 135.

${ }^{15}$ Clauretie and Herzog (1990) attribute these results to the rise in property values in California over the sample period, which presumably reduced loan losses.
} 
Fannie Mae's losses are higher in states that prohibit statutory rights of redemption and allow deficiency judgments.

To complicate the situation further, almost every state's law is idiosyncratic regarding statutory rights of redemption and deficiency judgments. It is easy to code state law with respect to judicial foreclosure processes, but not with respect to these two measures. Four papers in this literature code deficiency judgments differently, ${ }^{16}$ and even some lawyers specializing in foreclosure laws are unaware of whether a statutory right of redemption or a deficiency judgment is permitted in their state. ${ }^{17}$ The coding decisions made in this paper are described in the data appendix in table 1.

\section{The Effect of Foreclosure Law on Mortgage Supply and Demand}

As described in more detail below, if both lenders and borrowers take foreclosure laws into account when making their decisions, the effect of foreclosure laws on equilibrium loan size is ambiguous.

Lenders. Suppose many identical lenders compete by offering menus of loan contracts, indexed by loan size and interest rate. Borrowers pick the utility-maximizing contract from this menu and lenders make zero profits.

Defaulter-friendly foreclosure laws affect the lender's zero-profit curve in two ways: they increase the lender's losses if the borrower defaults and they increase the probability of default itself. To see this in a simple model, assume that if the borrower repays the loan, the lender receives the interest rate $(1+r)=R$ times the loan amount $L .^{18}$ If the borrower defaults, the lender takes back the house, valued at the downpayment

\footnotetext{
${ }^{16}$ See Clauretie (1989), Lin and White (2001), Wood (1997), and this paper.

${ }^{17}$ In an attempt to clarify some states' laws, I called local real estate law firms that specialized in foreclosure law.

${ }^{18}$ See Lehnert and Pence (2001) for a general equilibrium model of the effect of defaulter-friendly foreclosure laws on the supply of mortgage credit. See Ambrose, Buttimer, and Capone (1997) for a formal mortgage pricing model in which defaulter-friendly laws increase the probability of default.
} 
$D$ plus the loan amount $L$ times any stochastic change $(1+z)=Z$ in value since purchase. The lender must also pay the borrower a foreclosure benefit $k$ that is larger in defaulter-friendly states than in lender-friendly states. If $E$ is the expectations operator, the lender's zero profit curve is

$$
\operatorname{Pr}(\text { no default })(R L)+\operatorname{Pr}(\text { default })(E[Z(D+L)]-k)-I L=0
$$

To see that the loan terms affect the probability of default, assume that the borrower defaults if the gain from default, $k$, outweighs the gain from repaying the loan, $Z(D+$ $L)-R L .{ }^{19}$ This decision is driven by the stochastic change in house prices. At the trigger value $Z^{*}$, the borrower is indifferent between defaulting and not defaulting: $Z^{*}(D+L)-R L=k$ or

$$
Z^{*}=\frac{k+R L}{D+L}
$$

Higher values of $Z^{*}$ imply a higher probability of default. Assuming a fixed initial house value, $Z^{*}$ is increasing in $k, L$, and $R$, indicating that borrowers are more likely to default if they live in a state with generous foreclosure benefits. In addition, borrowers with higher loan-to-value ratios are more likely to default. To recoup these expected losses, lenders will charge more leveraged borrowers higher interest rates, so the lender's zero-profit curve slopes upward in $(L, R)$ space.

In summary, the lender's zero-profit curve shifts inward with the generosity of the foreclosure laws. Borrowers could experience this reduced credit supply as higher interest rates, higher downpayment requirements, or both.

Borrowers. If borrowers are aware of foreclosure laws when they purchase their homes, defaulter-friendly laws may increase their demand for mortgages. Considering

\footnotetext{
${ }^{19}$ Obviously, this simple model ignores transaction costs and the value of the option to default in the future, among other factors.
} 
housing solely as an asset, a borrower's expected return to financing a house is

$$
\max \{k, E[Z(D+L)]-R(k, L) L\}-D
$$

As the generosity of the foreclosure law $k$ increases, a borrower receives greater insurance against falling house prices. Generous foreclosure benefits also result in higher interest rates, thereby decreasing the wealth of a borrower who repays the mortgage. Suppose the increase in interest rates offsets the higher foreclosure benefits, so that the lender's expected profits are constant across states. Even so, a risk-averse borrower's utility from investing in housing is higher in a state with defaulter-friendly laws, because the borrower gains greater benefits at a time when the marginal utility of wealth is high.

It may seem implausible, however, that borrowers are aware of foreclosure laws when they purchase property. In a study of the effect of state bankruptcy laws on mortgage applications, for example, Berkowitz and Hynes (1999) assumed that loan demand does not respond to bankruptcy laws. ${ }^{20}$ In this case, the theory offers a clearcut prediction: unchanged mortgage demand and reduced mortgage supply imply a decrease in the equilibrium loan size.

Institutional Factors. Many mortgage market participants are skeptical that mortgage terms vary with foreclosure laws. Lenders assert that they do not take foreclosure costs into account when setting mortgage terms. In addition, they argue that the institutions that originate mortgages do not bear the costs of foreclosure. Most mortgages are sold to Fannie Mae, Freddie Mac, or other secondary market institutions soon after origination, and mortgages with the greatest risk of default are required to acquire private mortgage insurance (PMI).

Nonetheless, mortgage market participants are clearly aware that they face different foreclosure costs across states. Fannie Mae's vice president of credit portfolio manage-

\footnotetext{
${ }^{20}$ [W] e think that it is unlikely that most debtors are cognizant of, or estimate, [bankruptcy] exemptions at the time of borrowing." p. 812
} 
ment noted in an interview that "It is inefficient to have exactly the same foreclosurecost insurance coverage for every loan across the nation...because these costs vary from state to state." ${ }^{21}$ Furthermore, mortgage market participants do not have to know why their losses are higher in some areas of the country to adjust their loan terms.

Secondary mortgage market institutions and private mortgage insurers have largely the same information set as mortgage originators. Private mortgage insurers must approve an application before the originator accepts it, and in some circumstances Fannie Mae and Freddie Mac can give back loans to lenders on which they suffer disproportionate losses. Even with PMI, Freddie Mac and Fannie Mae suffer losses on foreclosures. Wood (1997) suggests that after collecting PMI, Fannie Mae's losses on mortgages with LTVs in the 80 to 85 percent range (which carry PMI) were 65 percent of their losses on mortgages with LTVs in the 75 to 80 percent range (which do not carry PMI). ${ }^{22}$ In addition, not all loans are sold to secondary market institutions; in 1995, only 57 percent of single-family mortgages were securitized. ${ }^{23}$

Lenders appear to have responded to foreclosure laws in the past by adjusting loan terms. As mentioned earlier, Jones (1993) documented that lenders responded to costly foreclosure laws in Canada by increasing downpayment requirements. Meador (1982) and Wood (1997) found higher interest rates in states with defaulter-friendly laws, while Alston (1984) found higher interest rates and a decreased supply of mortgages in states that prohibited foreclosures during the Great Depression.

Thus, if both borrowers and lenders incorporate foreclosure laws into their behavior, simple theory models do not predict how loan size varies with the laws. Mortgage market institutions also send conflicting signals about whether the laws affect their behavior. In the next sections, I examine empirically whether loan size varies with state foreclosure laws in the contemporary mortgage market when regional effects are controlled for fully.

\footnotetext{
${ }^{21}$ See Hochstein (2000).

${ }^{22}$ See Table 4.5 .

${ }^{23}$ See Freddie Mac (1999), p. 44 Table A6.
} 


\section{Estimation}

As mentioned previously, both foreclosure laws and real estate markets exhibit regional patterns, thereby raising concerns that a regional shock will be misinterpreted as an effect of the laws. I address this identification obstacle by selecting mortgage applications in groups of counties that border each other, yet are located in different states. These mortgage applications are subject to different foreclosure laws but may take on similar values for unobserved variables that would otherwise bias the analysis. Holmes (1998) and Black (1999) use a similar "borders" identification strategy to estimate the effect of state right-to-work laws on the location of manufacturing and the effect of school quality on house prices.

Because real estate markets vary across the United States, relevant variables unobserved by the econometrician may also vary substantially with location. To capture this unobserved variation as flexibly as possible, I implement a semiparametric estimator that allows unobserved variables to take on a different value at each census tract, yet still identifies the effect of the laws. As an added virtue, each mortgage on the data set is compared only with neighbors within a few mile radius, further incorporating the local nature of real estate markets.

In their studies of the effects of bankruptcy law on the mortgage market, Berkowitz and Hynes (1999) and Lin and White (2001) control for regional factors with state fixed effects models that exploit changes in bankruptcy law over time. This approach is not well suited to studies of foreclosure laws, however, because the laws rarely change. When foreclosure law changes do occur, they are rarely random events. Rather, they are usually precipitated by events such as the Great Depression, raising concerns of a correlation between the changes in the law and the mortgage market outcomes under study. In this context, a "borders" identification strategy is more appealing than a changes-over-time strategy.

To motivate the importance of my method, I first estimate two models that use 
standard parametric tools. First, I run a simple ordinary least squares regression that acknowledges regional effects only through its standard errors, which allow for correlation across observations within the same MSA. Then I run a fixed effects model that assigns a separate fixed effect to each group of counties. Because the correlation across observations may not be constant within an MSA, the standard errors in this model also allow for within-MSA correlations.

The fixed effects model, however, masks substantial heterogeneity both across and within county groups. Some county groups, such as the two counties in the area covered by Fargo, North Dakota, and Moorhead, Minnesota, are part of compact, homogeneous metropolitan areas, while others, such as the counties in the vast New York City area, are sprawling and heterogeneous. It may be undesirable to treat Fargo-Moorhead and New York City equivalently or to use a single fixed effect to describe the behavior of all the widely varying components of the New York City area. Another source of heterogeneity is county size: counties in the western United States are generally much larger than their eastern counterparts. Thus western county groups may extend farther from the border and encompass more variation. ${ }^{24}$ Finally, even the most careful attempts to group similar counties together will lead inevitably to some arbitrary classifications. These inflexible and arbitrary assumptions embedded in the fixed effects model may obscure the true relationship between foreclosure laws and mortgage market outcomes.

To control for regional factors in a more flexible manner, I estimate the following partial linear model, in which $y$ is the loan size, $\alpha$ is an unknown function that takes on a different value at each census tract, the matrix $X$ includes the foreclosure laws and other control variables, and $\epsilon$ is an idiosyncratic error term:

$$
y=\alpha(\text { census tract })+X \beta+\epsilon .
$$

\footnotetext{
${ }^{24}$ Arizona's 114,006 square miles are divided into 15 counties, for example, while Georgia's 59,441 miles are divided into 159 counties.
} 
Identification of $\beta$ in this model requires two assumptions. The first is that $\alpha$ is a smooth function. Under this assumption, the foreclosure law variables are identified, yet unobserved variables are allowed to take on a different value at each census tract. A model with a separate fixed effect for each census tract is not identified, because the fixed effects would be collinear with the foreclosure law variables. ${ }^{25}$ Yet a model in which a smooth function takes on a different value at each census tract is identified because the function changes smoothly at the state border, while the foreclosure laws change discontinuously. This identification strategy fits into the regression discontinuity framework discussed by Hahn, Todd, and Van der Klaauw (2001) and Porter (2002).

To be certain that I am capturing the effects of the laws, I must control for all other factors that change at state borders and may be correlated with foreclosure laws and the mortgage market outcomes under study. Stated more formally, the second identification assumption is the familiar $E(\epsilon \mid X$, census tract $)=0$. As discussed in the next section, I control for a rich assortment of state laws, county policies, and neighborhood characteristics that change discontinuously at the state border. I also examine the sensitivity of my results to a variety of robustness tests that include removing selected borders, MSAs, and states from the sample.

Figure 4 graphs the $\alpha$ function over the northeastern United States. The graph suggests that the smoothness identification assumption is reasonable: $\alpha$ does not change in value - or equivalently, in shade - at almost any of the borders depicted. The graph also indicates that the $\alpha$ function corresponds reasonably well to idiosyncratic variation in the real estate market. Specifically, areas that experienced greater growth in house prices over the 1990-94 period take on higher values. ${ }^{26}$ As discussed in the data section, the dependent variable in the specification is the log of the loan size in 1994 or 1995, while one of the independent variable is the log of 1990 house prices. Because of

\footnotetext{
${ }^{25}$ Census tracts are defined so as not to span state lines.

${ }^{26}$ The change in house prices was calculated with the Office of Federal Housing Enterprise Oversight House Price Index, available at http://www.ofheo.gov/house/.
} 
the log transformation, any percentage change in house prices over the 1990-94 period that affects loan sizes should be absorbed in the intercept $\alpha$ function.

Estimating the partial linear model. I estimate this model using the method outlined in Robinson (1988), who suggests taking the expectations of all terms in the model with respect to (in this application) the geographic location of the census tract

$E(y \mid$ census tract $)=E(\alpha($ census tract $) \mid$ census tract $)+E(X \mid$ census tract $) \beta$.

Then the partial linear model can be rewritten as

$$
y-E(y \mid \text { census tract })=[X-E(X \mid \text { census tract })] \beta+\epsilon .
$$

The term $\alpha$ (census tract) drops out of the equation because it equals its expectation.

Following Robinson (1988), I estimate the expected value of the dependent variable $y$ and independent variables in $X$, conditional on the census tract, with NadarayaWatson kernel regression. I subtract these expected values from the actual values, creating the residuals $y-E(y \mid$ census tract $)$ and $X-E(X \mid$ census tract $)$. Running ordinary least squares on these residuals yields an estimate of $\beta$. With the estimate of $\beta$ in hand, $\alpha$ can be calculated as $E(y \mid$ census tract $)-E(X \mid$ census tract $) \beta$.

As calculated by kernel regression, the expected value of a variable in a given census tract is simply the weighted average of the variables in surrounding tracts. The weighting scheme, also known as the kernel, places greater weight on geographically close census tracts than on those farther away. The statistics literature suggests that the choice of kernel has only a small effect on the estimates; I use both the Epanechnikov kernel and the triangular kernel.

The bandwidth governs which census tracts are included in the weighted aver- 
age. For example, with a small bandwidth, only nearby census tracts are used in the weighted average. The bandwidth used in this paper is somewhat unusual because it is measured in miles. While the usual kernel estimator of the density $f$ at a point $x$ is written

$$
\hat{f}(x)=\frac{1}{n h} \sum_{i=1}^{n} K\left(\frac{x_{i}-x}{h}\right)
$$

where $K$ is the kernel, $n$ is the sample size, and $h$ is the bandwidth, this paper's kernel takes the form

$$
\hat{f}(x)=\frac{1}{n h} \sum_{i=1}^{n} K\left(\frac{\text { distance between census tract } x_{i} \text { and } x \text { in miles }}{h}\right) .
$$

Distances are calculated between the geographic centers of the census tracts using the Haversine formula. ${ }^{27}$

Kernel regression estimates can be sensitive to the choice of bandwidth. I estimate an optimal bandwidth for each variable using cross-validation and also experiment with bandwidths slightly larger and smaller than these ideal bandwidths. ${ }^{28}$ Another alternative, though, is that the distance measure should be adjusted for population density. Unobserved characteristics may change more rapidly in dense urban neighborhoods than in sparsely settled areas. Thus I also use variants of the following bandwidth, in which area is the area in square miles of the census tract:

$$
d=\left(\frac{\min (4 \sqrt{\text { area of first tract, }} 20)+\min (4 \sqrt{\text { area of second tract, }} 20)}{2}\right) .
$$

Since census tracts are designed to have a roughly constant number of people, population density is approximately inversely proportional to census tract area. Taking the

\footnotetext{
${ }^{27}$ The Haversine formula takes the curvature of the earth into account. See http://www.census.gov/cgibin/geo/gisfaq?Q5.1.

${ }^{28}$ Specifically, I perform cross-validation by minimizing the estimated prediction error, as discussed in Pagan and Ullah (1999), p. 119.
} 
average ensures that the estimator is symmetrical, in the sense that if tract $A$ is within the maximum distance from tract $B, \operatorname{tract} B$ is within a maximum distance of tract $A$, and both distances receive the same weight. The value " 20 " guards against outliers by imposing an upper bound on the maximum distance. The mean of this bandwith is 6.5 miles and the median is 4.3 .

Under the method outlined by Robinson (1988), $\beta$ converges at a $\sqrt{n}$ rate even though $\alpha$ converges at the semiparametric rate. Standard errors can be estimated using the conventional ordinary least squares formula. Porter (2002) shows, however, that in a regression-discontuity context, $\beta$ converges at a slower rate and the conventional standard error formula cannot be relied on. To address these concerns, I bootstrap the standard errors using a design matrix or pairwise bootstrap.

\section{Data}

Geography. As a first step to implementing the borders estimation strategy, I select counties in the United States that are part of a metropolitan statistical area (MSA) as defined by the Census Bureau; that lie along state borders; and that border another metropolitan county. I impose this "metropolitan" requirement because the Home Mortgage Disclosure Act, my data source, does not require lenders to report mortgage applications for nonmetropolitan counties. This selection criteria yields 181 counties, which I sort into 55 groups of cohesive and geographically contiguous counties, listed in table 2. Some of these groups, such as the three counties in the Charlotte-GastoniaRock Hill MSA that lie along the North Carolina-South Carolina border, are from the same MSA; others, such as the westernmost county of the Pensacola, Florida, MSA and the easternmost county of the Mobile, Alabama, MSA, are from different MSAs. Although counties from the same MSA form a more natural comparison group, the partial linear model compares properties within a couple miles of each other; these properties should take on similar values of unobserved variables regardless of whether 
they are technically in the same MSA. ${ }^{29}$

This sample will yield estimates of the effects of the laws only if a sizeable number of bordering counties have different legal structures. Despite the regional pattern of foreclosure law, the maps in figures 1 through 3, which superimpose the 55 county groups on the foreclosure law maps, suggest that there is still substantial variation on which to base the analysis. Turning first to the judicial foreclosure requirement, 28 county groups, shown in black in figure 1 and listed in table 3 , contain at least one state that requires a judicial foreclosure and one state that allows a power-of-sale procedure. These county groups are spread across the United States; thus, they are unlikely to be dominated by a single regional effect. Furthermore, they are located in densely populated areas of the United States, so the partial linear regression estimates are based on a large number of mortgage applications near the border. In total, these counties contain 776,588 mortgage applications.

Estimation of the effects of statutory rights of redemption and deficiency judgments, however, appears more problematic. As shown in figures 2 and 3 and in tables 4 and 5 , nine county groups contain one state that requires a statutory right of redemption and one state that does not; five county groups contain one state that prohibits deficiency judgments and one that does not. These counties are concentrated in the Midwest - four of the five "deficiency judgment" borders include either Minnesota or Iowa - and in less populated areas of the country, with 87,679 applications in the statutory right-of-redemption groups and 75,154 in the deficiency judgment groups. Earlier I argued that there was a stronger link between lender costs and judicial foreclosure processes than between these costs and either statutory rights of redemption or deficiency judgments. These estimation issues suggest that even if such a relationship exists, it may be hard to discern using this approach.

Tables 3, 4, and 5 also list whether the county group's border is a river. Since rivers

\footnotetext{
${ }^{29}$ Nonetheless, as shown later in the paper, I perform a robustness test in which the sample includes only county groups from the same MSA; this restriction does not change the results.
} 
are a barrier to interaction, geographically close census tracts may be less similar in their unobserved characteristics when they are separated by a river. ${ }^{30}$ Fourteen of the judicial borders are separated by a river, ten are not, and four have partial river borders. For these four pairs, I code the counties individually to indicate whether they are separated by a river. Discarding borders that coincide with rivers reduces the statutory right-of-redemption sample to four borders and the deficiency judgment sample to one border.

Loan application data. Under federal law, mortgage lending institutions with assets above a certain threshold are required to report basic information on every mortgage application that they receive in a metropolitan statistical area. ${ }^{31}$ The federal government uses this information to assess whether mortgage lenders are serving the housing credit needs of their communities. The HMDA data include characteristics of the borrower (sex, race, income, presence of co-applicant) and the loan (amount, type, purpose, if the property is owner-occupied). The data also list the census tract in which the property is located, whether the application was approved, and the name of the lending institution. HMDA data are available from the Federal Financial Institutions Examination Council for the years 1990 through 2001. The data sets are enormous: the 1994 HMDA data, for example, contain over 12 million loan applications.

I use the data from 1994 and 1995 for my estimation. These years strike a balance between competing goals: earlier years provide a better match to the 1990 Census, whereas later years reflect the most recent trends in the mortgage market. ${ }^{32}$ I limit the sample to accepted applications for the purchase of owner-occupied, one- to fourfamily homes. I exclude all loans originated by manufactured housing lenders, since

\footnotetext{
${ }^{30}$ Hoxby (2000) and Cutler and Glaeser (1997) use rivers as instruments in studies of the effects of school choice and segregation, respectively. They find that the number of rivers is positively correlated with the number of school districts and the degree of segregation; these findings suggest that rivers affect interactions.

${ }^{31}$ This limit was $\$ 10$ million until 1996, \$28 million in 1997, and \$29 million in 1998 and 1999 . The 1998 HMDA data included an estimated $75 \%$ of all home purchase loans (Canner, Passmore, and Laderman (1999)).

${ }^{32}$ Practical reasons also dictate use of 1994 and 1995. HMDA did not include 1990 census tract identifiers until 1992, and the regulations governing which institutions are required to report under HMDA changed in 1993 and 1996. In addition, the quality of the data is believed to have increased over time.
} 
the underwriting standards for some of these loans are closer to auto loans than home mortgages. I also delete loans for less than $\$ 10,000$; loans with missing or invalid census tract identifiers; and loans in which the borrower claimed to have zero income. After imposing these restrictions, I am left with a sample of 1,252,562 loan applications in metropolitan counties along state borders.

Neighborhood characteristics. I obtain additional information about borrowers' neighborhoods by merging variables from the 1990 Census onto the HMDA data for the tract in which the property is located. Neighborhood characteristics affect the demand for housing and the riskiness of the loan. In addition, if people sort into neighborhoods in which the residents are like them, the neighborhood characteristics may proxy for unobserved applicant characteristics that are correlated with default.

As described in more detail in the data appendix in table 1, I include characteristics of the tract residents, including their age, education level, and employment status. These variables affect a borrower's demand for housing and ability to repay a mortgage. I also include characteristics of the housing stock, such as median house value, median year built, and percent owner-occupied. The quality of the housing stock affects demand for housing as well as the volatility of neighborhood house prices, which in turn increases default risk. For each tract, I also obtain its predicted crime rates, its geographic area (measured in square miles), and the latitude and longitude of its geographic center.

State and county laws and policies. Bankruptcy laws, like foreclosure laws, vary dramatically across states. A borrower who files for a chapter 7 bankruptcy retains equity in the home up to the state-specific homestead exemption and retains other assets up to the personal property exemption. All other assets are forfeited to repay creditors. In 1994, homestead exemptions varied from $\$ 0$ to unlimited across states, while personal property exemptions varied from $\$ 2,000$ to $\$ 40,500 .{ }^{33}$

\footnotetext{
${ }^{33}$ Andreas Lehnert generously provided this data. The data appendix in table 1 provides details on the coding of these variables.
} 
Bankruptcy laws appear to affect the mortgage market, but the direction of the effect is unclear. A borrower can declare bankruptcy without defaulting on a mortgage. So long as home equity is less than the homestead exemption, bankruptcy proceedings do not necessarily affect the mortgage lender. Indeed, Berkowitz and Hynes (1999) and Agarwal, Chomsisengphet, and Elul (2002) argue that generous bankruptcy exemptions decrease the probability of mortgage default because borrowers have more funds with which to repay their mortgages. However, Lin and White (2001) note that generous exemptions increase the probability that a borrower will file for bankruptcy and that foreclosure proceedings are substantially more expensive when bankruptcy is involved. Adding more confusion, Berkowitz and Hynes (1999) and Lin and White (2001) find opposite results when they examine, using the HMDA data, whether borrowers are more likely to be denied mortgage credit in states with generous bankruptcy exemptions. I provide an independent test of the effect of bankruptcy laws by including the homestead and personal property exemptions in the specification. This paper is, to my knowledge, among the first to include the full set of bankrupty and foreclosure laws. $^{34}$

Other state and local policies that may affect housing demand are state income taxes, proxied here by the maximum income tax rate in the state; county per-pupil spending; and county property taxes per capita. Property taxes may affect house prices by signaling the local level of public goods provision or by indicating a higher financial burden for homeowners. I also include the number of homebuilding permits per capita and the number of banks per capita in each county, a possible indicator of the degree of competition among local mortgage lenders.

Table 6 contains sample means and standard deviations for the variables in the specification. The table indicates that 62 percent of the mortgage applications in the sample are in states that require a judicial foreclosure process; 7 percent are in states that require a statutory right of redemption; and 6 percent are in states that forbid

\footnotetext{
${ }^{34}$ Agarwal, Chomsisengphet, and Elul (2002) also includes the full set of legal variables.
} 
deficiency judgments. The average foreclosure process took 185 days.

Specification Implications. The variables on the HMDA data pose two issues for the specification. First, the data do not include the value of the property associated with the loan. I proxy for this house value with census tract housing characteristics such as the median house value in the tract and with the $\alpha$ function, which, as shown earlier, appears to soak up some of the local variation in house prices. If these variables capture the house price variation fully, the coefficient on the foreclosure law variables will reflect the effect of the laws on the loan-to-value ratio. If not, the coefficient may also express the effect of the laws on the value of the property. If borrowers have a more difficult time obtaining mortgage credit, they may not be willing to pay as much for a house. Lehnert and Pence (2001) model this dynamic explicitly and present evidence that foreclosure laws are capitalized into house prices. In the present paper, I cannot rule out this explanation completely.

Second, authors such as Berkowitz and Hynes (1999) and Lin and White (2001) have used the HMDA data to examine whether state laws affect the probability that a mortgage application is rejected. Many borrowers, though, consult with lenders before formally filing a mortgage application. Lenders may tell borrowers how to shape their applications to maximize their chances of approval; they might suggest, for example, that a larger downpayment would increase their probability of acceptance. If borrowers adapt their applications accordingly, denial rates may not differ across states even if loan terms do. In addition, denial rates may be higher in states that are less risky for lenders, because lenders in these states may solicit and encourage marginal loan applications more aggressively. ${ }^{35}$ Instead of focusing on denial rates, I focus on the loan sizes of accepted applications in this paper.

\footnotetext{
${ }^{35}$ Canner, Passmore, and Laderman (1999), for example, note that subprime lenders generally have higher denial rates than prime lenders, partly because of their active solicition of marginal loan applications.
} 


\section{Results}

To preview the results, I find that loan sizes are smaller in states with defaulter-friendly foreclosure laws and that unobserved regional factors can play an influential role in estimating this relationship. Table 7 presents results for the foreclosure law parameters for the ordinary least squares, fixed effects, and partial linear models. All specifications use the log of the loan size as the dependent variable. The ordinary least squares and fixed effects models employ Eicker-White standard errors that are robust to heteroskedasticity and that allow for arbitrary correlations across observations within the same MSA. The partial linear model uses a triangular kernel and a bandwidth of ten miles for every variable, slightly larger than the nine mile bandwidth that the cross-validation algorithm indicated was appropriate for the judicial foreclosure and statutory right-ofredemption variables. Standard errors in the partial linear model are bootstrapped with 200 replications.

Table 7 provides dramatic evidence of a connection between loan size and a judical foreclosure requirement once regional factors are accounted for properly. The ordinary least squares specification, shown in the first column, suggests that there is no relationship between a judicial foreclosure requirement and loan size. The coefficient is essentially zero in both size and statistical significance, a somewhat astonishing finding in a specification with $1,252,562$ observations. Accounting for regional factors with county group fixed effects, however, suggests that loan sizes are a statistically significant 3.5 percent smaller in states with judicial foreclosure requirements. Controlling for geography in an even more flexible manner via the partial linear model yields an even stronger result: loan sizes are 6.8 percent smaller in judicial foreclosure states. This estimate is also statistically significant. These results suggest the reduced mortgage supply in states with a judicial foreclosure requirement dominates any effect of the laws on mortgage demand.

Unlike the judicial foreclosure requirement, even after introducing regional con- 
trols loan sizes appear to be unaffected by statutory rights of redemption. This provision is associated with a statistically insignificant 1.5 percent decrease in loan size in the ordinary least squares specification and 0.7 percent increase in the fixed effects specification, as well as with a borderline-significant 1.7 increase in the partial linear specification. Since very few households exercise a statutory right of redemption, it is not surprising to see no connection between this provision and the mortgage market. In addition, this result is based on a relatively small sample of borders.

The deficiency judgment results vary considerably with the specification, presumably because of the small sample of loan applications on which these estimates are based. However, as noted earlier, other researchers have also had difficulty robustly estimating the effects of deficiency judgments. In the ordinary least squares specification, loan sizes are an implausible 13 percent higher in states that forbid deficiency judgments. In the fixed effects specification, the deficiency judgment coefficient is essentially zero, while the partial linear regression estimates suggest that loan sizes are 5 percent higher in states that prohibit deficiency judgments. While deficiency judgment prohibitions may affect the mortgage market, this paper's approach may not reliably estimate their effect.

Table 7 also contains the estimates and standard errors for the other parameters in the model. The coefficients suggest that the bankruptcy homestead exemption is negatively correlated with loan size, while the bankruptcy personal property exemption is positively correlated with loan size. However, neither exemption appears to have a substantial effect on the mortgage market: the estimate suggests that a 1,000 percent increase in the homestead exemption is associated with a 4 percent decrease in loan size. Although the personal property coefficient is the larger of the two, this difference probably reflects the size of the exemptions: the homestead exemption ranges from $\$ 0$ to $\$ 500,000$ across states, while the personal property exemption ranges from $\$ 2,000$ to $\$ 40,500 .{ }^{36}$

\footnotetext{
${ }^{36}$ I top-code the homestead exemption at $\$ 500,000$ for states with unlimited homestead exemptions and
} 
The other state and county variables have similarly small effects. A \$1,000 increase in per-pupil spending is associated with a 0.8 percent (fixed effects) or 1.6 percent (partial linear) increase in loan size; a 1 percentage point increase in the maximum state income tax is associated with a 0.003 percent (fixed effects) or 0.002 percent (partial linear) increase in loan size; and a $\$ 100$ increase in property taxes per capita is associated with a 0.003 percent (fixed effects) or 0.002 percent (partial linear) decrease in loan size. The loan application and census tract variables generally follow sensible patterns - loan size increases with income, for example. ${ }^{37}$ Borrowers who are typically downpayment constrained - minority borrowers and those who take out FHA and VA loans - have larger loan sizes, controlling for census tract housing characteristics.

Fixed effects robustness tests. Turning back to the fixed effects model, we might worry that some of the county groups represent inappropriate comparison groups. In some county groups, the areas on either side of the border represent different metropolitan statistical areas (MSAs). By definition, MSAs are areas with high degrees of social and economic integration; different MSAs, even if they are geographically contiguous, may take on different values of unobserved variables. In other county groups, the state border coincides with a river. Due to this barrier to interaction, the areas on either side of the river may have developed differently and thus have dissimilar values of the unobserved variables. ${ }^{38}$

To address these concerns, table 8 shows fixed effects estimates for two subgroups: county groups composed of only one MSA and county groups not separated by a river. The estimates suggest that loan sizes are 5.4 percent smaller when the sample is restricted to same-MSA counties and are 5 percent smaller when the sample is restricted

add "one" to each state's value before taking the log of the homestead exemption. I use the logarithmic transformation of the exemptions because their distributions are skewed. Entering the exemptions linearly into the specification or using dummy variables for exemption quantiles does not change the sign or statistical significance of the bankruptcy exemption coefficients.

${ }^{37}$ In interpreting the census tract estimates, note that the "percent" variables are stored as whole numbers. For example, 20 percent is 20 not 0.2 .

${ }^{38}$ See table 2 for a list of same-MSA county groups and tables 3,4 , and 5 for a list of county groups in which rivers are not a border. 
to no-river border counties; both estimates are statistically significant. Thus, restricting the sample to more homogeneous groups of counties appears to increase somewhat the association between loan size and a judicial foreclosure requirement. The statutory right-of-redemption coefficient behaves fairly consistently, hovering near zero in both robustness tests. However, the deficiency judgment coefficient ranges from - 0.11 in the "no rivers" test to 0.04 in the "same MSA" test.

In another robustness test, I measure the costliness of the laws with the anticipated length of the foreclosure process, instead of with dummy variables for judicial foreclosure, statutory right of redemption, and deficiency judgment. This measure comes from Freddie Mac's guidelines and captures subtle differences between states with roughly similar laws. ${ }^{39}$ Kentucky and Wisconsin both have judicial foreclosure processes, for example, but the anticipated foreclosure length is 138 days in Kentucky and 300 days in Wisconsin. ${ }^{40}$ As noted earlier, states with lengthy foreclosure processes tend to be states that require a judicial foreclosure. On average, judicial foreclosures take 148 days longer than power-of-sale foreclosures; ${ }^{41}$ the difference between the quickest and most time-consuming states, according to Freddie Mac's guidelines, is 289 days.

The results from this days specification are consistent with the foreclosure law dummy results. A 100-day increase in the length of the foreclosure process is associated with a 1.8 percent decrease in loan size; a 200-day increase is associated with a 3.6 percent decrease in loan size, almost identical to the judicial parameter in the earlier specification.

Next, every county group potentially contains some idiosyncratic factor that might make it an inappropriate comparison group. To ensure that the results are not driven by any such idiosyncratic factor, I run the fixed-effect specification 55 times, each time

\footnotetext{
${ }^{39}$ See Jankowski (1999), pp. 2-11.

${ }^{40}$ Judicial foreclosure processes mandate a waiting period between the judge's order to sell the property and the actual sale. The borrower can stop the foreclosure at any point during this period by paying off the entire loan balance. This period extends for one to two months in Kentucky and six to twelve months in Wisconsin. These kinds of differences drive the varying lengths of the foreclosure processes.

${ }^{41}$ See Wood (1997).
} 
excluding a different county group from the estimation. I also run a parallel exercise in which I exclude each state from the data set in turn. Table 9 shows the smallest and largest parameter values resulting from these specifications, along with the name of the corresponding excluded MSA or state.

The results suggest that no one MSA or state exerts an undue influence on the judicial foreclosure parameter estimate. The estimates range from -0.046 to -0.03 for the MSA specifications and from -0.047 to -0.025 for the state specifications, neatly bracketing the original point estimate, -0.035 . The statutory right-of-redemption coefficients span zero but remain fairly small in magnitude. The deficiency judgment coefficient is more volatile, ranging from -0.027 to 0.049 in the MSA specifications and from -0.035 to 0.05 in the state specifications.

In a final robustness test, I run the model separately over 1994 and 1995 out of a concern that time trends in the mortgage market may be distorting the results. The judicial coefficient is almost identical in both years: -0.037 in 1994 and -0.034 in 1995 . These results are not shown in the tables but are available upon request.

Partial linear robustness tests. The partial linear model results can be sensitive to the choice of bandwidth and kernel. To examine the robustness of the estimates to these choices, tables 10 and 11 show results from seven bandwidth - kernel combinations. Four specifications use the same bandwidth for every bandwidth and every census tract. These bandwidths - eight and ten miles - bracket the optimal bandwidth for the judicial foreclosure parameter (nine miles), as determined by the cross-validation algorithm. Two other specifications also impose the same bandwidth on every variable but allow this bandwidth to vary with population density. The final specification uses the optimal bandwidth, as determined by cross-validation, for every variable.

The coefficient on the judicial foreclosure parameter is remarkably stable across specifications, ranging from -0.053 to -0.072 . Regardless of the choice of kernel or the form of the bandwidth, the coefficient indicates a negative, statistically signifi- 
cant relationship between a judicial foreclosure requirement and loan size. Decreasing the bandwidth increases the standard errors, a finding that is consistent with the biasvariance tradeoff in kernel estimation. The Epanechnikov specifications also exhibit smaller standard errors, consistent with its "optimal kernel" reputation. ${ }^{42}$ However, the point estimates do not differ across kernels, thereby reinforcing the conventional wisdom that kernel choice is unimportant. The robustness of the parameter estimate to small changes in bandwidth suggests that the bandwidth choices are reasonable.

The coefficient on the statutory right of redemption is less stable, switching signs as I move from a fixed-mile bandwidth to a bandwidth that varies with population density. This instability does not result from a sub-optimal bandwidth choice, since the crossvalidation algorithm suggests that nine miles is also the optimal bandwidth for this parameter. The deficiency judgment coefficients are also variable, ranging from 0.05 to 0.10 , although their sign and statistical significance are constant across specifications. As with the earlier fixed effects results, these results do not appear robust to changes in the specification.

\section{Conclusion}

In this paper I establish a robust inverse relationship between a judicial foreclosure requirement and mortgage loan size. This relationship holds in both a simple model with MSA fixed effects and in a more flexible semiparametric model in which unobserved variables take on a different value at every census tract. The relationship does not hold when I ignore the regional pattern of foreclosure laws; this result underscores the importance of controlling for these factors.

Statutory rights of redemption, in contrast, do not appear to affect the mortgage market substantively. Since few borrowers exercise this right, this result is not surprising. The effect of a prohibition on deficiency judgments varies across specifications.

\footnotetext{
${ }^{42}$ See Pagan and Ullah (1999), pp. 27-28.
} 
Both coefficients are based on a limited number of borders and are not, in general, measured precisely; some previous authors have also had difficulty estimating their effects robustly.

This paper also highlights a way of applying partial linear regression that is useful for estimating the effects of state laws and policies. The method compares observations to neighbors within a few miles, thereby incorporating regional effects in a flexible manner. Moreover, it controls for any unobserved factors that vary smoothly with distance-a plausible assumption for many research questions with a spatial component.

Overall, the results from this estimation suggest that borrowers in states with defaulterfriendly laws face a reduced supply of mortgage credit. Of course, even at this price, borrowers in these states may still value the insurance provided by generous foreclosure laws. Nonetheless, the results highlight a largely unexamined tradeoff: defaulterfriendly foreclosure laws may assist homeowners experiencing hard times, but they also impose costs on a much larger pool of borrowers at the time of loan origination. Although a decade-long run-up in house prices has precluded much discussion of foreclosures, recent increases in foreclosure rates may bring renewed interest in this tradeoff. 


\section{References}

Agarwal, S., S. Chomsisengphet, and R. Elul (2002). Personal bankruptcy exemptions and mortgage default. Unpublished manuscript, Brown University.

Alston, L. (1984). Farm foreclosure moratorium legislation: A lesson from the past. American Economic Review 74, 445-457.

Ambrose, B. W., R. J. Buttimer, Jr., and C. A. Capone (1997). Pricing mortgage default and foreclosure delay. Journal of Money, Credit and Banking 29(3), 31425.

Ambrose, B. W., C. A. Capone, Jr., and Y. Deng (2001). Optimal put exercise: An empirical examination of conditions for mortgage foreclosure. Journal of Real Estate Finance and Economics 23(2), 213-234.

Barta, P. (2001). Pinched homeowners are finding shelter in modified loans. Wall Street Journal October 30, A1.

Berkowitz, J. and R. Hynes (1999). Bankruptcy exemptions and the market for mortgage loans. Journal of Law and Economics 42(2), 809-830.

Black, S. (1999, May). Do better schools matter? Parental valuation of elementary education. Quarterly Journal of Economics 114(2), 557-599.

Bridewell, D. (1938, January). The effect of defective mortgage laws on home financing. Law and Contemporary Problems 5, 545-563.

Canner, G. B., W. Passmore, and E. Laderman (1999, November). The role of specialized lenders in extending mortgages to lower-income and minority homebuyers. Federal Reserve Bulletin 85(11), 709-723.

Capone, Jr., C. A. (1996). Providing Alternatives to Mortgage Foreclosure: A Report to Congress. Washington, D.C.: U.S. Department of Housing and Urban Development.

Ciochetti, B. A. (1997, Spring). Loss characteristics of commercial mortgage foreclosure. Real Estate Finance, 53-69.

Clauretie, T. M. (1989). State foreclosure laws, risk shifting, and the PMI industry. Journal of Risk and Insurance 56(3), 544-554.

Clauretie, T. M. and T. Herzog (1990). The effect of state foreclosure laws on loan losses: Evidence from the mortgage insurance industry. Journal of Money, Credit and Banking 22(2), 221-233.

Cutler, D. M. and E. L. Glaeser (1997, August). Are ghettos good or bad? Quarterly Journal of Economics 112(3), 827-872.

Fleishman, S. (2002). Facing foreclosure. Washington Post February 2, H1.

Freddie Mac (1999, April). Secondary Mortgage Markets 16(1).

Gropp, R., J. K. Scholz, and M. J. White (1997). Personal bankruptcy and credit supply and demand. Quarterly Journal of Economics 112(1), 217-51. 
Hahn, J., P. Todd, and W. Van der Klaauw (2001, January). Identification and estimation of treatment effects with a regression-discontinuity design. Econometrica 69(1), 201-9.

Hochstein, M. (2000, October 23). Fannie Mae out to eat private mortgage insurers' lunch again? American Banker 165(203), 3A.

Holmes, T. (1998). The effect of state policies on the location of manufacturing: Evidence from state borders. Journal of Political Economy 106(4), 667-705.

Hoxby, C. M. (2000, December). Does competition among public schools benefit students and taxpayers? American Economic Review 90(5), 1209-1238.

Jankowski, D. (1999). National Mortgage Servicers Reference Directory (16 ed.). Perry Hall, MD: Vernon Enterprises.

Jones, L. D. (1993, April). Deficiency judgments and the exercise of the default option in home mortgage loans. Journal of Law and Economics 36(1), 115-38.

Keyles, S. A. (1995). Foreclosure law and related remedies : A state-by-state digest. Chicago, Ill.: Section of Real Property, Probate and Trust Law, American Bar Association.

Lehnert, A. and D. M. Maki (2002). Consumption, debt, and portfolio choice: Testing the effects of bankruptcy law. Finance and Economics Discussion Series 2002-14, Federal Reserve Board, Washington, D.C.

Lehnert, A. and K. M. Pence (2001). The price of protection: Foreclosure law, mortgages and house prices. Unpublished manuscript, Federal Reserve Board, Washington D.C.

Lin, E. Y. and M. J. White (2001). Bankruptcy and the market for mortgage and home improvement loans. Journal of Urban Economics 50(1), 138-62.

Meador, M. (1982). The effect of mortgage laws on home mortgage rates. Journal of Economics and Business 34, 143-148.

Pagan, A. and A. Ullah (1999). Nonparametric Econometrics. Cambridge, UK: Cambridge University Press.

Polk (1988, February). Stop the attack of the equity skimmers. Mortgage Banking 48(5), 82-4.

Porter, J. (2002). Asymptotic bias and optimal convergence rates for semiparametric kernel estimators in the regression discontinuity model. Working paper, Harvard University.

Poterba, J. M. (1991). House price dynamics: The role of tax policy and demography. Brookings Papers on Economic Activity 1991(2), 143-83.

Robinson, P. M. (1988). Root-N-semiparametric regression. Econometrica 56(4), 931-954.

Touche, Ross and Co. (1975). The Cost of Mortgage Loan Foreclosures: Case Studies of Six Savings and Loan Associations.

Wood, C. (1997). The Impact of Mortgage Foreclosure Laws on Secondary Market Loan Losses. Ph. D. thesis, Cornell University. 
TABLe 1: Data Appendix - Sources and Variable Definitions

Data Type

Source

Variables

\section{Foreclosure Laws}

Jankowski (1999), cross-checked with Keyles (1995) and with applicable case law if necessary. Judicial foreclosure procedure: Nineteen states allow only judicial procedures. I also code Oklahoma and Hawaii as judicial foreclosure states because no lenders use the prohibitively costly nonjudicial procedures in these states. The National Mortgage Servicers Reference Directory states that Oklahoma's nonjudicial procedure is "rarely exercised" (p. 7-159) because all borrowers can elect the judicial foreclosure process instead. In Hawaii, lenders do not pursue nonjudicial foreclosures because no title company will insure these mortgages (Jankowski (1999), p. 7-59). In 1999, five years after my HMDA data, Hawaii changed its law to make it easier for lenders to obtain nonjudicial foreclosures. Nonjudicial procedures are used widely in all other states that offer them.

Statutory right of redemption: I code a state as permitting a statutory right of redemption if the borrower always has that option under the foreclosure process (judicial or power-of-sale) that is standard in that state. New Jersey allows a ten-day statutory right of redemption under the standard power-of-sale foreclosure procedure. Since this period is substantially less than the sixmonth to one-year period allowed in other states, I code New Jersey as not allowing a statutory right of redemption. Under this definition, nine states allow a statutory right of redemption.

Deficiency judgment: I code a state as forbidding deficiency judgments if they are not permitted under the foreclosure process (judicial or power of sale) that is standard in that state.

\section{Consumer Bankruptcy Law}

Lehnert and Maki (2002) Appendix A

1994 and 1995 homestead and personal property exemptions, by state, for unmarried households. I use the natural log of the exemptions because their distributions have long right tails. I add " 1 " to the homestead exemption before taking the log because it equals zero in some states.

\section{Borrower and Loan Characteristics}

1994 and 1995 Home Mortgage Disclosure Act

Loan size; income; census tract; dummy variables for conventional, FHA, VA, and FmHA loans; for black, Hispanic, and other race, and single female borrowers; and for applications with a coapplicant. 
Data Type

Source

Variables

Neighborhood Population and Housing Characteristics

1990 Census; as extracted by CensusCD+Maps

Age: Percent of residents who are 0-17, 18-21, 22-29, 30-39, 40-49, 50-59, 60-69, or 70 years and older.

Education: Percent of residents 25 years or older who did not finish high school, finished high school, attended some college, graduated from college, or attended some graduate school.

Labor force participation: Percent of residents 16 years or older who are employed, unemployed, or out of the workforce.

Housing characteristics: Percent of homes that are owner-occupied, rented, vacant, or mobile; median home age, median rent, median house value.

Census tract homicide and robbery index scores

CAP Index, Inc.: www.capindex.com.

Indexes for homicides and robberies per census tract, as predicted by the CAP Index model. The index runs from 0 to 2000; 100 is the national average. Because of the long right tail, I take the natural $\log$ of both variables.

\section{Lender characteristics}

U.S. Department of Housing and Urban Development

Dummy variables indicating whether the lender associated with the HMDA mortgage application specializes in subprime or manufactured home lending.

\section{State Tax Rates}

NBER Taxsim model: www.nber.org/taxsim/state-rates/

Maximum state tax rate for 1994 or 1995, as applicable. The maximum rate is thought to be less tarnished with endogeneity.

\section{County building permits per capita, 1994}

Bureau of the Census extracted via CensusCD + Maps

Building permits per capita for new, private, one-unit housing structures, 1994. Available by county.

County property taxes per capita, 1992

1992 Census of State and Local Governments extracted via CensusCD+Maps

\section{Commercial and saving bank offices per capita, 1994}

Federal Deposit Insurance Corporation extracted via CensusCD+Maps

Available by county. 
Table 1 (continued from previous page)

Data Type

Source

Variables

\section{County per-pupil spending}

Fiscal Year (FY) 1995 Public Elementary-Secondary Education Finances data from the Census Department's Annual Survey of Government Finances

FY 1995 covers the September 1994 - June 1995 school year. Since the FY 1994 data is a survey that excludes some school districts, while the FY 1995 data is a census that covers all school districts, I use the FY 1995 data for both years of HMDA data. To calculate county per pupil spending, I sum all current spending (TCURELSC) for all schools in the county and divide it by the sum of all students in the county (V33). Only public schools are included in this calculation. Since capital expenditures are erratic in their timing, excluding capital spending from per-pupil spending is standard in the education literature. 
Table 2: Metropolitan Areas and Counties in the Sample

\begin{tabular}{|c|c|c|c|}
\hline \multirow{2}{*}{$\begin{array}{c}\text { County Group Name } \\
\text { County Name }\end{array}$} & \multicolumn{2}{|r|}{ County Group Name } & \multirow[b]{2}{*}{ Obs } \\
\hline & Obs & County Name & \\
\hline Mobile AL-Pensacola FL & & Las Cruces NM - El Paso TX & \\
\hline Baldwin County, Alabama & 4029 & Dona Ana County, New Mexico & 3743 \\
\hline Escambia County, Florida & 7657 & El Paso County, Texas & 12738 \\
\hline Mobile AL-Pascagoula MS & & Wilmington NC-Myrtle Beach SC & \\
\hline Jackson County, Mississippi & 3358 & Brunswick County, North Carolina & 1880 \\
\hline Mobile County, Alabama & 9313 & Horry County, South Carolina & 6010 \\
\hline New Orleans LA-Gulfport MS & & Charlotte-Gastonia-Rock Hill NC-SC ${ }^{*}$ & \\
\hline Hancock County, Mississippi & 1028 & Gaston County, North Carolina & 4004 \\
\hline St. Tammany Parish, Louisiana & 6723 & Mecklenburg County, North Carolina & 24805 \\
\hline Columbus GA-AL ${ }^{*}$ & & York County, South Carolina & 3697 \\
\hline Muscogee County, Georgia & 3558 & Johnson City-Kingsport-Bristol TN* & \\
\hline Russell County, Alabama & 785 & Hawkins County, Tennessee & 886 \\
\hline Memphis TN-AR-MS * & & Sullivan County, Tennessee & 3781 \\
\hline Crittenden County, Arkansas & 1362 & Washington County, Virginia & 1075 \\
\hline DeSoto County, Mississippi & 3797 & Erie PA - Cleveland $\mathrm{OH}$ & \\
\hline Shelby County, Tennessee & 26989 & Ashtabula County, Ohio & 2241 \\
\hline Tipton County, Tennessee & 1271 & Chautauqua County, New York & 2358 \\
\hline Texarkana TX-Texarkana AR * & & Erie County, Pennsylvania & 6820 \\
\hline Bowie County, Texas & 2148 & Wheeling WV-OH ${ }^{*}$ & \\
\hline Miller County, Arkansas & 891 & Belmont Ohio & 1256 \\
\hline Fort Smith AR-OK * & & Marshall West Virginia & 562 \\
\hline Crawford County, Arkansas & 1426 & Ohio County, West Virginia & 918 \\
\hline Sebastian County, Arkansas & 3288 & Pittsburgh PA - Steubenville OH & \\
\hline Sequoyah County, Oklahoma & 631 & Beaver County, Pennsylvania & 3294 \\
\hline Reno NV & & Hancock County, West Virginia & 534 \\
\hline Placer County, California & 7508 & Jefferson County, Ohio & 1155 \\
\hline Washoe County, Nevada & 10984 & Washington County, Pennsylvania & 3808 \\
\hline Cheyenne WY-Fort Collins CO & & Youngstown-Warren OH Sharon PA & \\
\hline Laramie County, Wyoming & 3024 & Mahoning County, Ohio & 6455 \\
\hline Larimer County, Colorado & 8187 & Mercer County, Pennsylvania & 2513 \\
\hline Weld County, Colorado & 4610 & Trumbull County, Ohio & 4947 \\
\hline Chattanooga TN-GA* & & Parkersburg-Marietta WV-OH * & \\
\hline Catoosa County, Georgia & 1193 & Washington County, Ohio & 1629 \\
\hline Hamilton County, Tennessee & 7512 & Wood County, West Virginia & 2204 \\
\hline Walker County, Georgia & 1189 & Chicago-Gary IL-IN * & \\
\hline Minneapolis-St. Paul MN-WI * & & Cook County, Illinois & 123836 \\
\hline Dakota County, Minnesota & 12460 & Kankakee County, Illinois & 2885 \\
\hline St. Croix County, Wisconsin & 1803 & Lake County, Indiana & 11082 \\
\hline Washington County, Minnesota & 6982 & Will County, Illinois & 19428 \\
\hline led on next page & & & \\
\hline
\end{tabular}


Table 2 (continued from previous page)

\begin{tabular}{|c|c|c|c|}
\hline \multirow{2}{*}{$\begin{array}{c}\text { County Group Name } \\
\text { County Name }\end{array}$} & \multicolumn{2}{|r|}{ County Group Name } & \multirow[b]{2}{*}{$\mathrm{N}$} \\
\hline & $\mathrm{N}$ & County Name & \\
\hline Augusta-Aiken GA-SC * & & Baltimore, MD - York / Lancaster, PA & \\
\hline Aiken County, South Carolina & 3087 & Baltimore County, Maryland & 18138 \\
\hline Columbia County, Georgia & 3268 & Carroll County, Maryland & 4463 \\
\hline Richmond County, Georgia & 4138 & Harford County, Maryland & 6845 \\
\hline St. Louis MO-IL * & & Lancaster County, Pennsylvania & 11121 \\
\hline Jefferson County, Missouri & 5992 & York County, Pennsylvania & 10395 \\
\hline Madison County, Illinois & 7550 & Hartford, CT - Springfield MA & \\
\hline St. Charles County, Missouri & 11472 & Hampden County, Massachusetts & 8590 \\
\hline St. Clair County, Illinois & 6254 & Hartford County, Connecticut & 19013 \\
\hline St. Louis County, Missouri & 31476 & Tolland County, Connecticut & 3397 \\
\hline St. Louis City Missouri & 5939 & Poughkeepsie, NY - Danbury, CT ${ }^{*}$ & \\
\hline Davenport-Moline-IA-IL * & & Dutchess County, New York & 5142 \\
\hline Rock Island County, Illinois & 3956 & Fairfield County, Connecticut & 5826 \\
\hline Scott County, Iowa & 4716 & Putnam County, New York & 2310 \\
\hline Rockford IL-Beloit WI & & Lawrence, $\mathrm{MA}^{*}$ & \\
\hline Boone County, Illinois & 1410 & Essex County, Massachusetts & 16798 \\
\hline Rock County, Wisconsin & 4823 & Rockingham County, New Hampshire & 4304 \\
\hline Winnebago County, Illinois & 9462 & Lowell-Fitchburg MA Nashua NH ${ }^{*}$ & \\
\hline Chicago-Kenosha IL-WI * & & Hillsborough County, New Hampshire & 7360 \\
\hline Kenosha County, Wisconsin & 3939 & Middlesex County, Massachusetts & 32570 \\
\hline Lake County, Illinois & 23201 & Worcester County, Massachusetts & 2440 \\
\hline McHenry County, Illinois & 11214 & Providence RI, Attleboro-Worcester MA & \\
\hline Louisville KY-IN * & & Bristol County, Massachusetts & 10802 \\
\hline Clark County, Indiana & 2838 & Bristol County, Rhode Island & 1044 \\
\hline Floyd County, Indiana & 2176 & Hampden County, Massachusetts & 80 \\
\hline Harrison County, Indiana & 20 & Norfolk County, Massachusetts & 16720 \\
\hline Jefferson County, Kentucky & 20009 & Providence County, Rhode Island & 10284 \\
\hline Oldham County, Kentucky & 1470 & Windham County, Connecticut & 96 \\
\hline Evansville-Henderson IN-KY ${ }^{*}$ & & Worcester County, Massachusetts & 12904 \\
\hline Henderson County, Kentucky & 981 & New London, $\mathrm{CT}^{*}$ & \\
\hline Vanderburgh County, Indiana & 4721 & New London County, Connecticut & 6098 \\
\hline Warrick County, Indiana & 1905 & Washington County, Rhode Island & 2836 \\
\hline Clarksville-Hopkinsville TN-KY * & & Philadelphia-Wilmington-Atlantic City ${ }^{*}$ & \\
\hline Christian County, Kentucky & 1737 & Burlington County, New Jersey & 12777 \\
\hline Montgomery County, Tennessee & 5682 & Camden County, New Jersey & 11367 \\
\hline Shreveport LA-Marshall TX & & Cecil County, Maryland & 2120 \\
\hline Caddo Parish, Louisiana & 5748 & Chester County, Pennsylvania & 11001 \\
\hline Harrison County, Texas & 1237 & Delaware County, Pennsylvania & 10930 \\
\hline Lake Charles LA - Beaumont TX & & Gloucester County, New Jersey & 6266 \\
\hline Calcasieu Parish, Louisiana & 3971 & New Castle County, Delaware & 14425 \\
\hline Orange County, Texas & 1624 & Philadelphia County, Pennsylvania & 24026 \\
\hline
\end{tabular}


Table 2 (continued from previous page)

\begin{tabular}{|c|c|c|c|}
\hline \multirow{2}{*}{$\begin{array}{c}\text { County Group Name } \\
\text { County Name }\end{array}$} & \multicolumn{2}{|r|}{ County Group Name } & \multirow[b]{2}{*}{$\mathrm{N}$} \\
\hline & $\mathrm{N}$ & County Name & \\
\hline Cincinnati-Hamilton OH-KY-IN * & & Portland-Salem OR-WA * & \\
\hline Boone County, Kentucky & 2764 & Clark County, Washington & 12402 \\
\hline Butler County, Ohio & 9808 & Multnomah County, Oregon & 19925 \\
\hline Campbell County, Kentucky & 2569 & Portsmouth-Rochester $\mathrm{NH}^{*}$ & \\
\hline Clermont County, Ohio & 5335 & Rockingham County, New Hampshire & 2341 \\
\hline Dearborn County, Indiana & 1614 & Strafford County, New Hampshire & 1776 \\
\hline Hamilton County, Ohio & 21283 & York County, Maine & 1432 \\
\hline Kenton County, Kentucky & 4046 & New York City* & \\
\hline Omaha NE-IA * & & Bergen County, New Jersey & 18172 \\
\hline Douglas County, Nebraska & 10745 & Bronx County, New York & 4758 \\
\hline Pottawattamie County, Iowa & 1527 & Fairfield County, Connecticut & 18471 \\
\hline Sarpy County, Nebraska & 3109 & Hudson New Jersey & 5784 \\
\hline Kansas City MO-KS * & & Middlesex County, New Jersey & 16664 \\
\hline Cass County, Missouri & 2121 & New York New York & 9485 \\
\hline Clay County, Missouri & 5418 & Passaic County, New Jersey & 7924 \\
\hline Jackson County, Missouri & 15622 & Richmond County, New York & 7183 \\
\hline Johnson County, Kansas & 16605 & Rockland County, New York & 5470 \\
\hline Leavenworth County, Kansas & 1845 & Union County, New Jersey & 9420 \\
\hline Platte County, Missouri & 2347 & Westchester County, New York & 17724 \\
\hline Wyandotte County, Kansas & 2540 & Sussex, NJ-Port Jervis NY* & \\
\hline Huntington-Ashland WV-KY-OH * & & Orange County, New York & 5954 \\
\hline Boyd County, Kentucky & 1141 & Sussex County, New Jersey & 4101 \\
\hline Cabell County, West Virginia & 1812 & Trenton-Hunterdon NJ, Philadelphia & \\
\hline Greenup County, Kentucky & 752 & Bucks County, Pennsylvania & 16583 \\
\hline Lawrence County, Ohio & 1347 & Hunterdon County, New Jersey & 4324 \\
\hline Wayne County, West Virginia & 618 & Mercer County, New Jersey & 8540 \\
\hline Detroit MI -Toledo OH & & Easton, PA - Washington, NJ & \\
\hline Fulton County, Ohio & 1389 & Northampton County, Pennsylvania & 5910 \\
\hline Lenawee County, Michigan & 2733 & Warren County, New Jersey & 2759 \\
\hline Lucas County, Ohio & 12803 & Washington, $\mathrm{DC}^{*}$ & \\
\hline Monroe County, Michigan & 4156 & Arlington County, Virginia & 4305 \\
\hline Fargo-Moorhead ND-MN * & & District of Columbia & 9639 \\
\hline Cass County, North Dakota & 3538 & Fairfax County, Virginia & 32154 \\
\hline Clay County, Minnesota & 1298 & Frederick County, Maryland & 5745 \\
\hline South Bend IN - Benton Harbor MI & & Loudoun County, Virginia & 7941 \\
\hline Berrien County, Michigan & 4454 & Montgomery County, Maryland & 24910 \\
\hline St. Joseph County, Indiana & 7179 & Prince George's County, Maryland & 22333 \\
\hline Grand Forks ND-MN * & & Duluth-Superior MN-WI * & \\
\hline Grand Forks County, North Dakota & 1696 & Douglas County, Wisconsin & 1063 \\
\hline Polk County, Minnesota & 573 & St. Louis County, Minnesota & 4006 \\
\hline
\end{tabular}

* Indicates that all counties within a county group belong to the same metropolitan statistical area as defined by the Census Bureau. 
TABLE 3: JUdicial BORDERS

\begin{tabular}{ll}
\hline County Cross-Border Group & River \\
\hline \hline & \\
No river & \\
\hline & nort Smith AR-OK \\
South Bend IN - Benton Harbor MI & none \\
Clarksville-Hopkinsville TN-KY & none \\
Shreveport LA-Marshall TX & none \\
Detroit MI -Toledo OH & none \\
Wilmington NC-Myrtle Beach SC & none \\
Charlotte-Gastonia-Rock Hill NC-SC & none \\
Providence RI, Attleboro-Worcester & none \\
New London, CT & none \\
Hartford, CT - Springfield MA & none \\
Border is partially a river & \\
\hline & \\
Pittsburgh PA - Steubenville OH & Ohio/none \\
Portsmouth-Rochester NH & Piscataqua/none \\
Kansas City MO-KS & Missouri/none \\
Washington, DC & Potomac/none \\
Border is entirely a river & \\
\hline & \\
Mobile AL-Pensacola FL & Perdido \\
New Orleans LA-Gulfport MS & Pearl \\
Augusta-Aiken GA-SC & Savannah \\
St. Louis MO-IL & Mississippi \\
Davenport-Moline-Rock Island IA-IL & Mississippi \\
Huntington-Ashland WV-KY-OH & Ohio \\
Lake Charles LA - Beaumont TX & Sabine \\
Fargo-Moorhead ND-MN & Red River \\
Minneapolis-St. Paul MN-WI & St. Croix and Mississippi \\
Grand Forks ND-MN & Red River \\
Duluth-Superior MN-WI & Superior \\
Las Cruces NM - El Paso TX & Rio Grande \\
Wheeling WV-OH & Ohio \\
Parkersburg-Marietta WV-OH & Ohio \\
\hline
\end{tabular}


TABle 4: STATUTORY Right-OF-REDEMPTION BORDERS

\begin{tabular}{ll}
\hline County Cross-Border Group & River \\
\hline \hline Mobile AL-Pascagoula MS & none \\
South Bend IN - Benton Harbor MI & none \\
Detroit MI -Toledo OH & none \\
Kansas City MO-KS & none \\
Mobile AL-Pensacola FL & Perdido \\
Columbus GA-AL & Chattahoochee \\
Minneapolis-St. Paul MN-WI & St. Croix and Mississippi \\
Duluth-Superior MN-WI & Superior \\
Las Cruces NM - El Paso TX & Rio Grande \\
\hline
\end{tabular}

TABle 5: Deficiency Judgment Borders

\begin{tabular}{cl}
\hline County Cross-Border Group & River \\
\hline \hline Reno NV & none \\
Davenport-Moline-Rock Island IA-IL & Mississippi \\
Omaha NE-IA & Missouri \\
Minneapolis-St. Paul MN-WI & St. Croix and Mississippi \\
Duluth-Superior MN-WI & Superior \\
\hline
\end{tabular}


TAble 6: SAmple Statistics

\begin{tabular}{|c|c|c|}
\hline & Mean & Std. Dev. \\
\hline \multicolumn{3}{|l|}{ STATE LAWS } \\
\hline Judicial foreclosure & 0.62 & 0.49 \\
\hline Statutory right of redemption required & 0.07 & 0.25 \\
\hline Deficiency judgment prohibited & 0.06 & 0.23 \\
\hline Length of foreclosure process & 185.21 & 93.2 \\
\hline Log homestead exemption & 8.79 & 2.64 \\
\hline Log personal property exemption & 9.07 & 0.65 \\
\hline Maximum state income tax & 5.10 & 2.37 \\
\hline \multicolumn{3}{|l|}{ LOAN APPLICATION DATA } \\
\hline Log loan amount & 11.45 & 0.63 \\
\hline Log income & 10.83 & 0.63 \\
\hline Black & 0.09 & 0.28 \\
\hline Hispanic & 0.05 & 0.21 \\
\hline Other race & 0.05 & 0.23 \\
\hline Co-applicant & 0.67 & 0.47 \\
\hline Single female & 0.15 & 0.36 \\
\hline FHA mortgage & 0.16 & 0.37 \\
\hline VA mortgage & 0.06 & 0.23 \\
\hline FmHA mortgage & 0.00 & 0.04 \\
\hline \multicolumn{3}{|l|}{ CENSUS TRACT DATA } \\
\hline Pct households moved in 1960-69 & 9.69 & 5.78 \\
\hline Pct households moved in 1970-79 & 18.75 & 6.70 \\
\hline Pct households moved in $1980-84$ & 13.81 & 3.95 \\
\hline Pct households moved in $1985-88$ & 30.31 & 8.57 \\
\hline Pct households moved in 1989-90 & 18.37 & 8.69 \\
\hline Percent HS graduates & 29.03 & 9.44 \\
\hline Percent some college & 25.55 & 6.32 \\
\hline Percent college graduate & 17.20 & 9.49 \\
\hline Percent graduate degree & 9.88 & 8.22 \\
\hline Percent below poverty line & 6.99 & 7.23 \\
\hline Percent black residents & 7.88 & 16.7 \\
\hline Log 1989 per capita income & 9.74 & 0.39 \\
\hline Pct unemployed & 4.89 & 3.20 \\
\hline Percent Age 18-21 & 5.15 & 2.98 \\
\hline Percent Age 22-29 & 12.69 & 4.61 \\
\hline Percent Age 30-39 & 18.10 & 3.65 \\
\hline Percent Age 40-49 & 14.13 & 3.42 \\
\hline Percent Age 50-59 & 9.19 & 2.60 \\
\hline Percent Age 60-69 & 8.09 & 3.35 \\
\hline Percent Age 70+ & 7.58 & 4.63 \\
\hline Percent vacant & 5.89 & 5.53 \\
\hline Percent mobile homes & 3.41 & 7.84 \\
\hline continued on next page & & \\
\hline
\end{tabular}


Table 6 (continued from previous page)

\begin{tabular}{lrr}
\hline \hline & Mean & Std. Dev. \\
\hline \hline Percent rented & 25.58 & 16.6 \\
Pct 2 or 3 bedrooms & 66.45 & 14.9 \\
Pct 4 or 5 bedrooms & 22.03 & 15.6 \\
Median year built & 1964.08 & 13.9 \\
Log median house value & 11.59 & 0.60 \\
Median rent & 567.05 & 196 \\
Log of homicide score & 4.03 & 0.69 \\
Log of robbery score & 2.98 & 1.15 \\
CounTY DATA & & \\
Per-pupil spending (thousands) & 6.35 & 1.60 \\
Homebuilding permits per capita & 0.00 & 0.00 \\
Banks per capita & 0.00 & 0.00 \\
Property taxes per capita & 797.13 & 393 \\
Year & 1994.46 & 0.50 \\
\hline
\end{tabular}

FHA = Federal Housing Administration; VA = Department of Veterans Affairs; FmHA = Farmers Home Administration. 
TABle 7: Parameter Estimates

\begin{tabular}{|c|c|c|c|}
\hline Parameter & $\overline{\mathrm{OLS}}$ & Fixed Effects & Partial Linear \\
\hline \multicolumn{4}{|l|}{$\overline{\text { FORECLOSURE LAW VARIABLES }}$} \\
\hline \multirow[t]{2}{*}{ Judicial foreclosure } & -0.006 & -0.035 & -0.068 \\
\hline & $(0.013)$ & $(0.010)$ & $(0.005)$ \\
\hline \multirow[t]{2}{*}{ Statutory right of redemption required } & -0.015 & 0.007 & 0.017 \\
\hline & $(0.033)$ & $(0.023)$ & $(0.009)$ \\
\hline \multirow[t]{2}{*}{ Deficiency judgment prohibited } & 0.128 & -0.003 & 0.052 \\
\hline & $(0.055)$ & $(0.038)$ & $(0.008)$ \\
\hline \multicolumn{4}{|l|}{ 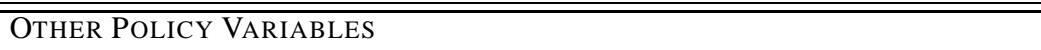 } \\
\hline \multirow[t]{2}{*}{ Log homestead exemption } & -0.010 & -0.007 & -0.004 \\
\hline & $(0.002)$ & $(0.002)$ & $(0.001)$ \\
\hline \multirow[t]{2}{*}{ Log personal property exemption } & -0.009 & 0.024 & 0.024 \\
\hline & $(0.013)$ & $(0.015)$ & $(0.002)$ \\
\hline \multirow[t]{2}{*}{ Per-pupil spending } & 0.005 & 0.008 & 0.016 \\
\hline & $(0.005)$ & $(0.008)$ & $(0.001)$ \\
\hline \multirow[t]{2}{*}{ Maximum state income tax } & -0.001 & 0.003 & 0.002 \\
\hline & $(0.003)$ & $(0.002)$ & $(0.001)$ \\
\hline \multirow[t]{2}{*}{ Property taxes per capita } & 0.000 & 0.000 & -0.000 \\
\hline & $(0.000)$ & $(0.000)$ & $(0.000)$ \\
\hline \multicolumn{4}{|l|}{ LOAN APPLICATION VARIABLES } \\
\hline \multirow[t]{2}{*}{ Log Income } & 0.454 & 0.450 & 0.444 \\
\hline & $(0.016)$ & $(0.015)$ & $(0.001)$ \\
\hline \multirow[t]{2}{*}{ Black } & 0.023 & 0.023 & 0.021 \\
\hline & $(0.007)$ & $(0.007)$ & $(0.002)$ \\
\hline \multirow[t]{2}{*}{ Hispanic } & 0.040 & 0.035 & 0.017 \\
\hline & $(0.019)$ & $(0.017)$ & $(0.002)$ \\
\hline \multirow[t]{2}{*}{ Other race } & 0.048 & 0.042 & 0.041 \\
\hline & $(0.010)$ & $(0.010)$ & $(0.002)$ \\
\hline \multirow[t]{2}{*}{ Co-applicant } & 0.075 & 0.077 & 0.075 \\
\hline & $(0.006)$ & $(0.006)$ & $(0.001)$ \\
\hline \multirow[t]{2}{*}{ Single female } & -0.018 & -0.019 & -0.020 \\
\hline & $(0.006)$ & $(0.006)$ & $(0.001)$ \\
\hline \multirow[t]{2}{*}{ FHA mortgage } & 0.056 & 0.056 & 0.057 \\
\hline & $(0.014)$ & $(0.015)$ & $(0.001)$ \\
\hline \multirow[t]{2}{*}{ VA mortgage } & 0.172 & 0.174 & 0.172 \\
\hline & $(0.011)$ & $(0.011)$ & $(0.001)$ \\
\hline \multirow[t]{2}{*}{ FHMA mortgage } & 0.105 & 0.092 & 0.097 \\
\hline & $(0.020)$ & $(0.021)$ & $(0.006)$ \\
\hline \multicolumn{4}{|c|}{ CENSUS TRACT AND COUNTY VARIABLES } \\
\hline \multirow[t]{2}{*}{ Pct households moved in 1960-69 } & 0.001 & 0.001 & 0.001 \\
\hline & $(0.001)$ & $(0.001)$ & $(0.0001)$ \\
\hline \multirow[t]{3}{*}{ Pct households moved in 1970-79 } & -0.001 & -0.002 & -0.002 \\
\hline & $(0.001)$ & $(0.001)$ & $(0.0001)$ \\
\hline & \multicolumn{3}{|c|}{ continued on next page } \\
\hline
\end{tabular}


Table 7 (continued from previous page)

\begin{tabular}{|c|c|c|c|}
\hline Parameter & 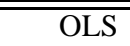 & Fixed Effects & Partial Linear \\
\hline Pct households moved in $1980-84$ & $\begin{array}{r}-0.000 \\
(0.001)\end{array}$ & $\begin{array}{r}-0.001 \\
(0.001)\end{array}$ & $\begin{array}{r}-0.002 \\
(0.0001)\end{array}$ \\
\hline Pct households moved in $1985-88$ & $\begin{array}{r}-0.000 \\
(0.001)\end{array}$ & $\begin{array}{r}-0.002 \\
(0.001)\end{array}$ & $\begin{array}{r}-0.002 \\
(0.0001)\end{array}$ \\
\hline Pct households moved in 1989-90 & $\begin{array}{r}-0.000 \\
(0.001)\end{array}$ & $\begin{array}{r}-0.002 \\
(0.001)\end{array}$ & $\begin{array}{c}-0.002 \\
(0.0001)\end{array}$ \\
\hline Percent HS graduates & $\begin{array}{r}-0.005 \\
(0.001)\end{array}$ & $\begin{array}{r}-0.002 \\
(0.001)\end{array}$ & $\begin{array}{r}-0.002 \\
(0.0001)\end{array}$ \\
\hline Percent some college & $\begin{array}{r}-0.001 \\
(0.001)\end{array}$ & $\begin{array}{r}-0.001 \\
(0.001)\end{array}$ & $\begin{array}{r}-0.000 \\
(0.0001)\end{array}$ \\
\hline Percent college graduate & $\begin{array}{r}-0.002 \\
(0.001)\end{array}$ & $\begin{array}{r}0.001 \\
(0.001)\end{array}$ & $\begin{array}{r}0.001 \\
(0.0001)\end{array}$ \\
\hline Percent graduate degree & $\begin{array}{r}-0.005 \\
(0.001)\end{array}$ & $\begin{array}{r}-0.004 \\
(0.001)\end{array}$ & $\begin{array}{r}-0.003 \\
(0.0002)\end{array}$ \\
\hline Percent below poverty line & $\begin{array}{r}-0.002 \\
(0.001)\end{array}$ & $\begin{array}{r}-0.001 \\
(0.001)\end{array}$ & $\begin{array}{r}-0.000 \\
(0.0001)\end{array}$ \\
\hline Percent black residents & $\begin{array}{r}0.001 \\
(0.001)\end{array}$ & $\begin{array}{r}0.000 \\
(0.001)\end{array}$ & $\begin{array}{r}-0.001 \\
(0.0001)\end{array}$ \\
\hline Log 1989 per capita income & $\begin{array}{r}0.010 \\
(0.034)\end{array}$ & $\begin{array}{r}-0.005 \\
(0.033)\end{array}$ & $\begin{array}{r}0.047 \\
(0.003)\end{array}$ \\
\hline Pct unemployed & $\begin{array}{r}-0.007 \\
(0.002)\end{array}$ & $\begin{array}{r}-0.005 \\
(0.001)\end{array}$ & $\begin{array}{c}-0.004 \\
(0.0002)\end{array}$ \\
\hline Percent vacant & $\begin{array}{r}-0.001 \\
(0.001)\end{array}$ & $\begin{array}{r}0.000 \\
(0.001)\end{array}$ & $\begin{array}{r}0.001 \\
(0.0002)\end{array}$ \\
\hline Percent mobile homes & $\begin{array}{r}-0.002 \\
(0.001)\end{array}$ & $\begin{array}{r}-0.001 \\
(0.000)\end{array}$ & $\begin{array}{r}-0.001 \\
(0.0001)\end{array}$ \\
\hline Percent rented & $\begin{array}{r}0.003 \\
(0.001)\end{array}$ & $\begin{array}{r}0.003 \\
(0.001)\end{array}$ & $\begin{array}{r}0.003 \\
(0.0001)\end{array}$ \\
\hline Pct 2 or 3 bedrooms & $\begin{array}{r}0.004 \\
(0.001)\end{array}$ & $\begin{array}{r}0.004 \\
(0.001)\end{array}$ & $\begin{array}{r}0.003 \\
(0.0001)\end{array}$ \\
\hline Pct 4 or 5 bedrooms & $\begin{array}{r}0.006 \\
(0.001)\end{array}$ & $\begin{array}{r}0.005 \\
(0.001)\end{array}$ & $\begin{array}{r}0.005 \\
(0.0001)\end{array}$ \\
\hline Median year built & $\begin{array}{r}-0.001 \\
(0.0004)\end{array}$ & $\begin{array}{r}-0.000 \\
(0.000)\end{array}$ & $\begin{array}{r}0.001 \\
(0.000)\end{array}$ \\
\hline Log median house value & $\begin{array}{r}0.381 \\
(0.022)\end{array}$ & $\begin{array}{r}0.360 \\
(0.023)\end{array}$ & $\begin{array}{r}0.269 \\
(0.003)\end{array}$ \\
\hline Median rent & $\begin{array}{r}0.000 \\
(0.000)\end{array}$ & $\begin{array}{r}-0.000 \\
(0.000)\end{array}$ & $\begin{array}{c}-0.000 \\
(0.000)\end{array}$ \\
\hline Percent Age 18-21 & $\begin{array}{r}0.001 \\
(0.001)\end{array}$ & $\begin{array}{r}0.000 \\
(0.001)\end{array}$ & $\begin{array}{r}-0.001 \\
(0.0002)\end{array}$ \\
\hline Percent Age 22-29 & $\begin{array}{r}-0.003 \\
(0.002)\end{array}$ & $\begin{array}{r}-0.003 \\
(0.002)\end{array}$ & $\begin{array}{r}-0.004 \\
(0.0002)\end{array}$ \\
\hline
\end{tabular}


Table 7 (continued from previous page)

\begin{tabular}{lrrr}
\hline \hline Parameter & OLS & Fixed Effects & Partial Linear \\
\hline \hline Percent Age 30-39 & 0.003 & 0.001 & -0.001 \\
Percent Age 40-49 & $(0.002)$ & $(0.001)$ & $(0.0002)$ \\
& 0.001 & -0.002 & -0.003 \\
Percent Age 50-59 & $(0.002)$ & $(0.001)$ & $(0.0002)$ \\
& -0.002 & -0.003 & -0.005 \\
Percent Age 60-69 & $(0.001)$ & $(0.001)$ & $(0.0002)$ \\
& -0.003 & -0.006 & -0.006 \\
Percent Age 70+ & $(0.001)$ & $(0.001)$ & $(0.0002)$ \\
& -0.001 & -0.001 & -0.002 \\
Log of homicide score & $(0.001)$ & $(0.001)$ & $(0.0002)$ \\
& 0.016 & 0.040 & 0.039 \\
Log of robbery score & $(0.012)$ & $(0.009)$ & $(0.001)$ \\
& -0.019 & -0.042 & -0.041 \\
Homebuilding permits per capita & $(0.011)$ & $(0.009)$ & $(0.001)$ \\
& 7.721 & 1.848 & 5.343 \\
Banks per capita & $(2.451)$ & $(1.436)$ & $(0.316)$ \\
& -256.72 & -71.210 & -178.07 \\
Year & $(91.46)$ & $(61.10)$ & $(20.44)$ \\
& -0.024 & -0.023 & -0.023 \\
\hline \hline $\mathrm{N}$ & $(0.004)$ & $(0.004)$ & $(0.0007)$ \\
$\mathrm{R}^{2}$ & & $1,252,562$ & \\
\hline
\end{tabular}

NotE. The dependent variable in the regression is $\log (\operatorname{loan}$ size). Eicker-White standard errors that allow for within-MSA correlations are shown in parentheses for the OLS and fixed effects specifications. Bootstrapped standard errors based on 200 replicates are shown for the partial linear regression specification. Partial linear regression estimates based on a bandwidth of ten miles and a triangular kernel. 
TAble 8: Fixed EfFects Robustness Tests

\begin{tabular}{lrrr}
\hline Parameter & Base Spec & Same MSA & No River \\
\hline \hline Judicial foreclosure & -0.035 & -0.054 & -0.050 \\
& $(0.010)$ & $(0.016)$ & $(0.015)$ \\
Statutory right of redemption required & 0.007 & 0.008 & -0.017 \\
& $(0.023)$ & $(0.035)$ & $(0.031)$ \\
Deficiency judgment prohibited & -0.003 & 0.041 & -0.11 \\
& $(0.038)$ & $(0.036)$ & $(0.028)$ \\
\hline \hline Days & -0.00018 & n.a. & n.a. \\
& $(0.00006)$ & n.a. & n.a. \\
\hline \hline $\mathrm{N}$ & $1,252,562$ & 944,966 & 818,297 \\
$\mathrm{R}^{2}$ & 0.58 & 0.59 & 0.59 \\
& 0.59 & (days specification) \\
\hline \hline
\end{tabular}

Note. The dependent variable in the regression is $\log (\operatorname{loan}$ size). Eicker-White standard errors that allow for within-MSA correlations are shown in parentheses. MSA = metropolitan statistical area.

TABle 9: “LeAve-One-OuT” FiXed EFFECts Robustness Tests

\begin{tabular}{lrrrr}
\hline \multirow{2}{*}{ Parameter } & \multicolumn{2}{c}{ MSA } & \multicolumn{2}{c}{ State } \\
& Min Value & Max Value & Min Value & Max Value \\
\hline \hline Judicial foreclosure & -0.046 & -0.030 & -0.047 & -0.025 \\
& $(0.012)$ & $(0.010)$ & $(0.012)$ & $(0.009)$ \\
& Washington DC & New York City & Maryland & Connecticut \\
& & & & \\
Statutory right of & -0.006 & 0.021 & -0.014 & 0.027 \\
redemption required & $(0.025)$ & $(0.022)$ & $(0.026)$ & $(0.027)$ \\
& Las Cruces NM & New York City & Wisconsin & Connecticut \\
Deficiency judgment & -0.027 & & & \\
prohibited & $(0.034)$ & $(0.036)$ & -0.035 & 0.050 \\
& Davenport IA & Reno NV & Wisconsin & California \\
& & & & \\
\hline \hline
\end{tabular}

NOTE. The dependent variable in the regression is $\log (\operatorname{loan}$ size). Eicker-White standard errors that allow for within-MSA correlations are shown in parentheses. MSA = metropolitan statistical area. 
Table 10: Partial Linear Regression Robustness Tests

\begin{tabular}{lcccc}
\hline \hline \multirow{2}{*}{ Kernel: } & \multicolumn{2}{c}{ Triangular } & \multicolumn{2}{c}{ Epanechnikov } \\
\cline { 2 - 5 } Bandwidth: & $10 \mathrm{mi}$ & $8 \mathrm{mi}$ & $10 \mathrm{mi}$ & $8 \mathrm{mi}$ \\
\hline \multirow{2}{*}{ Judicial foreclosure } & -0.068 & -0.071 & -0.067 & -0.072 \\
& $(0.004)$ & $(0.005)$ & $(0.004)$ & $(0.005)$ \\
Statutory right of redemption & 0.017 & 0.022 & 0.015 & 0.019 \\
& $(0.008)$ & $(0.010)$ & $(0.008)$ & $(0.008)$ \\
Deficiency judgment prohibited & 0.052 & 0.055 & 0.050 & 0.054 \\
& $(0.009)$ & $(0.010)$ & $(0.008)$ & $(0.009)$ \\
\hline \hline
\end{tabular}

NOTE. The dependent variable in all regressions is $\log (\operatorname{loan}$ size). Bootstrapped standard errors based on 200 replicates are shown in parentheses.

Table 11: More Partial Linear Regression Robustness Tests

\begin{tabular}{lcccc}
\hline \hline \multirow{2}{*}{ Kernel: } & \multicolumn{4}{c}{ Triangular } \\
\cline { 2 - 5 } Bandwidth: & $10 \mathrm{mi}$ & $\min (4 \sqrt{\operatorname{area}}, 20)$ & $\min (3 \sqrt{\operatorname{area}}, 20)$ & CVAL \\
\hline \multirow{2}{*}{ Judicial foreclosure } & -0.068 & -0.053 & -0.054 & -0.085 \\
& $(0.004)$ & $(0.005)$ & $(0.006)$ & $(0.005)$ \\
Statutory right of redemption & 0.017 & -0.038 & -0.040 & 0.038 \\
& $(0.008)$ & $(0.011)$ & $(0.014)$ & $(0.009)$ \\
Deficiency judgment prohibited & 0.052 & 0.10 & 0.082 & 0.049 \\
& $(0.009)$ & $(0.017)$ & $(0.021)$ & $(0.009)$ \\
\hline \hline
\end{tabular}

NotE. The dependent variable in all regressions is $\log (\operatorname{loan}$ size). Bootstrapped standard errors based on 200 replicates are shown in parentheses. CVAL $=$ optimal crossvalidation bandwidth used for every variable in the regression. 


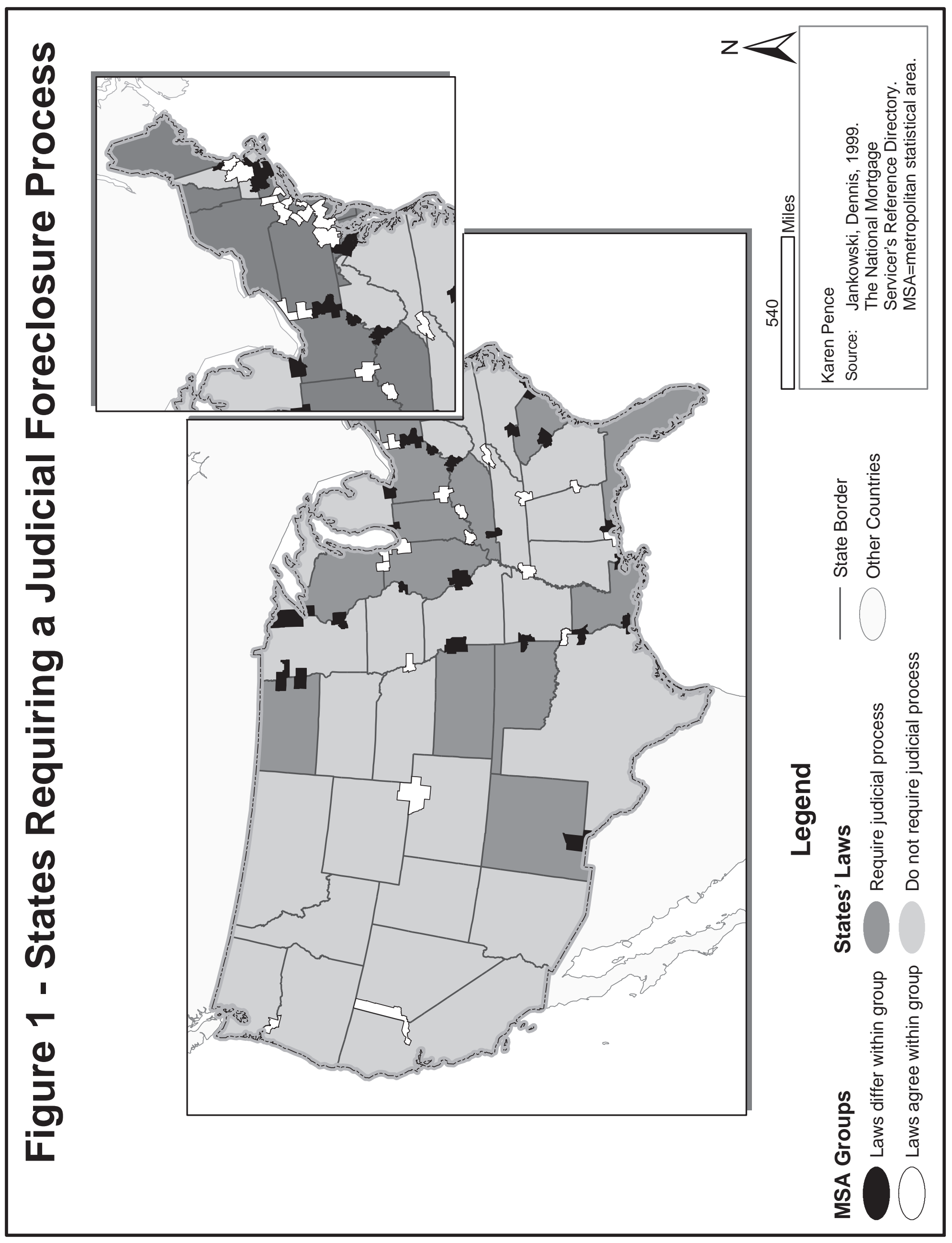




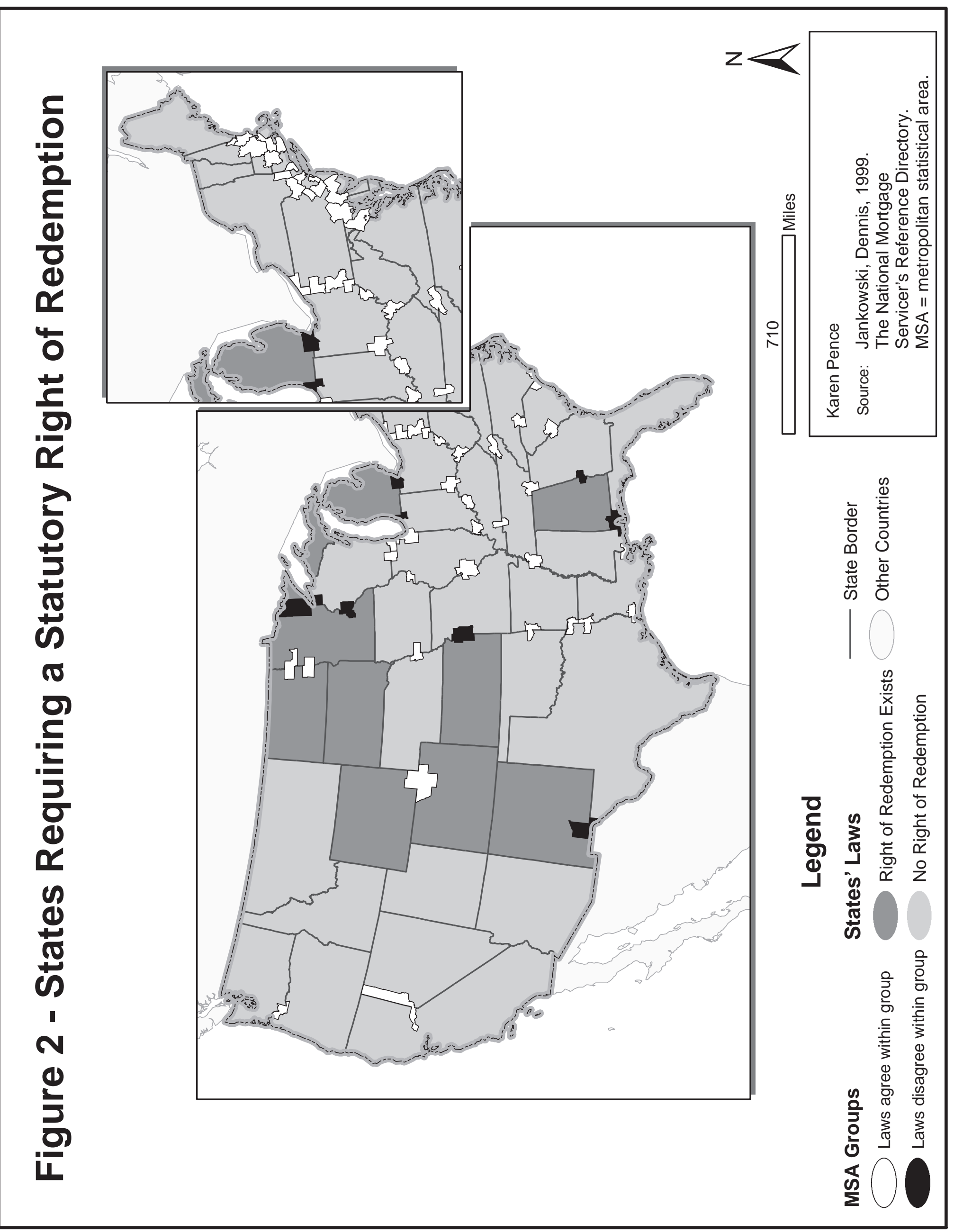




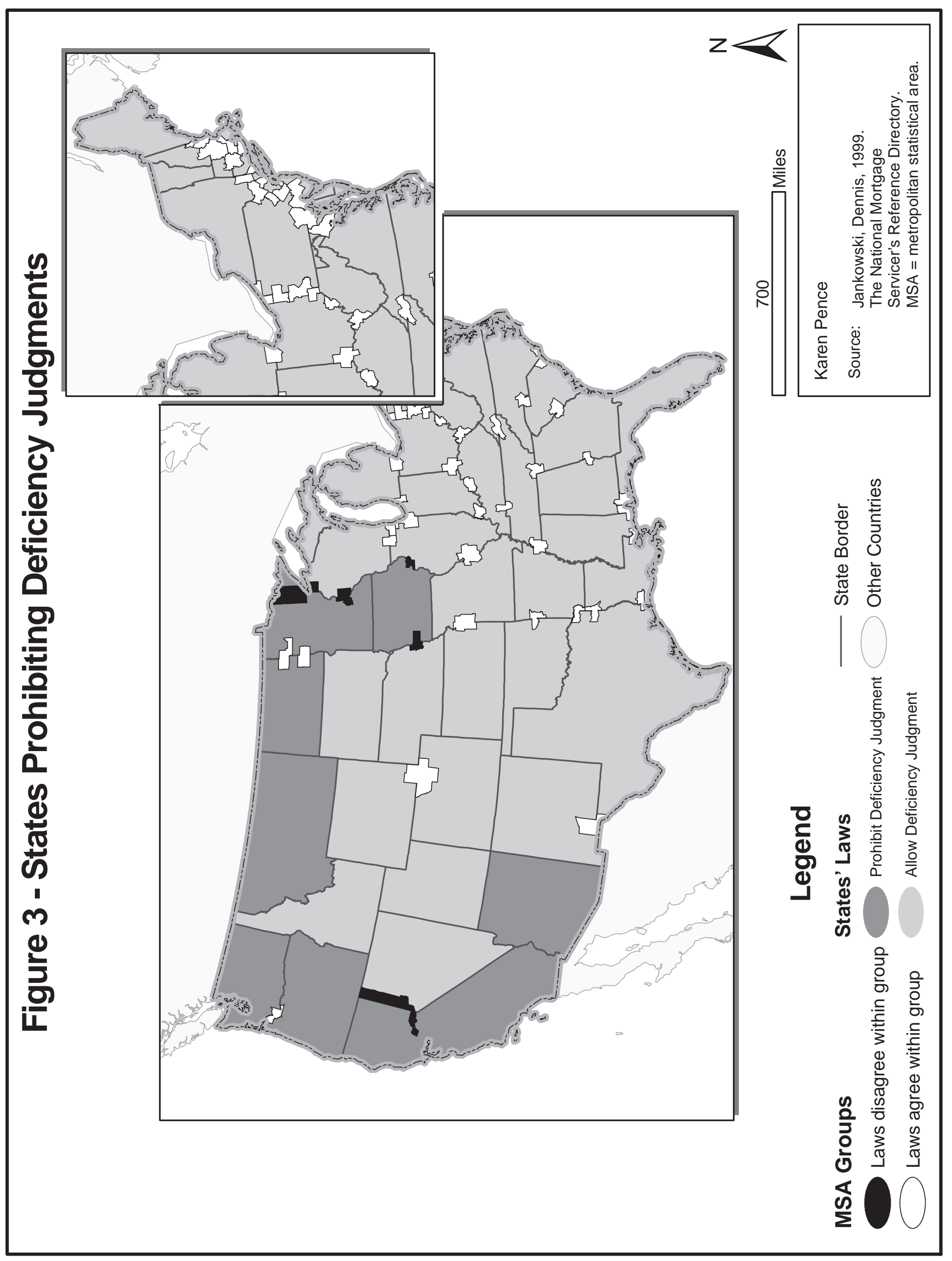




\section{Figure 4 - Alpha Function from the Partial Linear Model, Northeastern United States}

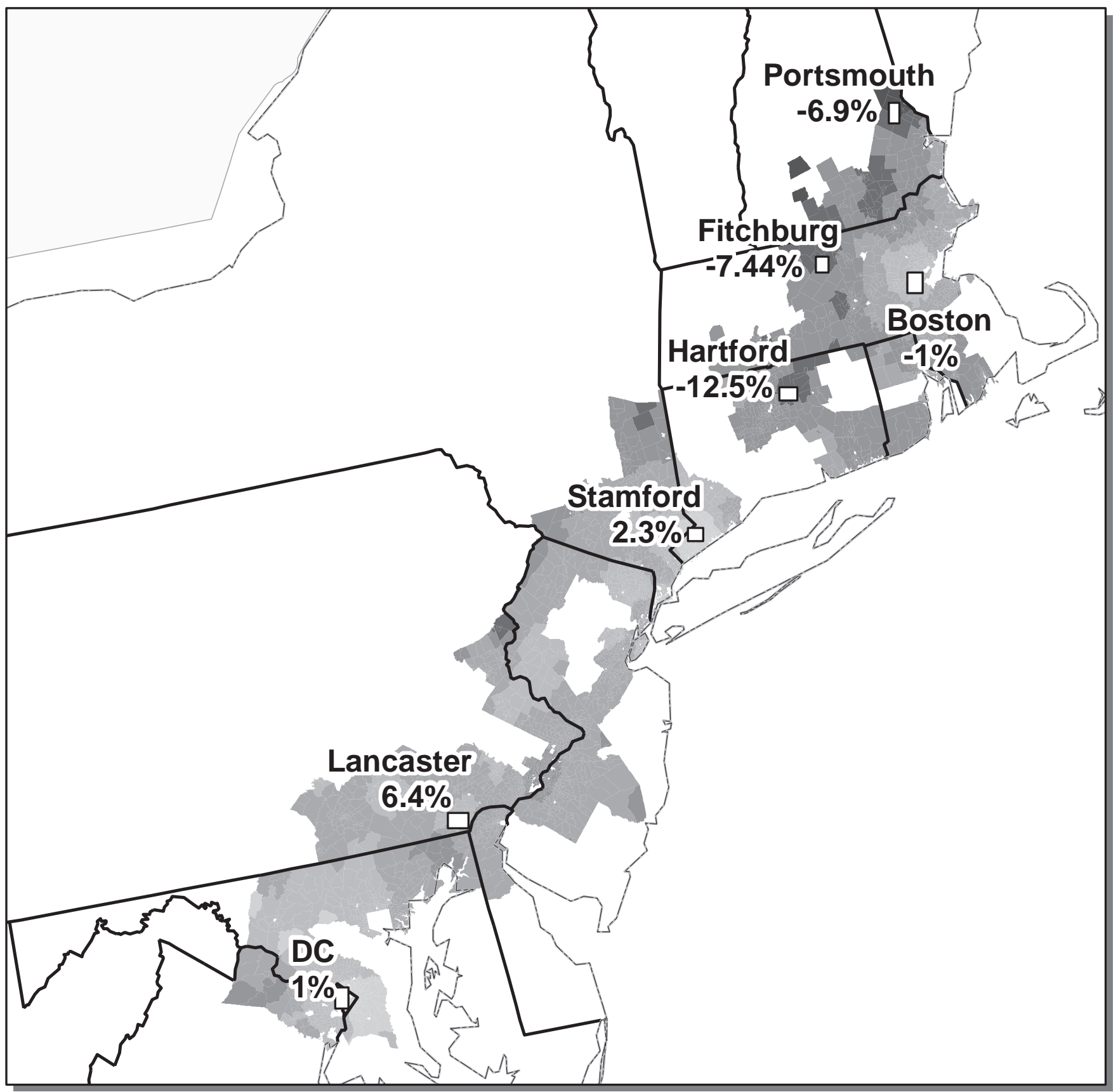

Legend

State Border

\section{Alpha}

Less than -3 Std. Dev.

-3 to -2 Std. Dev.
Change in the OFHEO

House Price Index, 1990:Q4 - 1994:Q4

-2 to -1 Std. Dev.

-1 to 0 Std. Dev.

0 to 1 Std. Dev.

1 to 2 Std. Dev.

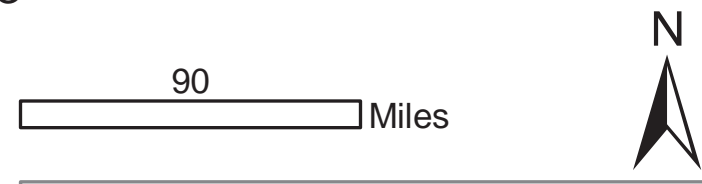

Karen Pence

Source: Home Mortgage Disclosure Act data, Census.

OFHEO=Office of Federal Housing Enterprise Oversight 